\section{SOI: $1.1 /$ TAS DOI: $10.15863 /$ TAS International Scientific Journal Theoretical \& Applied Science}

p-ISSN: 2308-4944 (print) $\quad$ e-ISSN: 2409-0085 (online)

Year: 2017 Issue: $01 \quad$ Volume: 45

Published: 19.01.2017 $\quad \underline{\text { http://T-Science.org }}$
Denis Chemezov

Master of Engineering and Technology, Corresponding Member of International Academy of Theoretical and Applied Sciences, Lecturer of Vladimir Industrial College, Russian Federation chemezov-da@yandex.ru

SECTION 2. Applied mathematics. Mathematical modeling.

\title{
THE FINITE ELEMENT MODELING OF THE FLUID FLOW IN THE PIPELINES WITH THE COMPLEX LOCAL HYDRAULIC RESISTANCES
}

Abstract: The article was made a computer analysis of dynamics of the fluid flow in the union cross and the tees. The results of finite element modeling are presented: the values of the velocity change of the fluid flow on different sections of the local resistance; the calculated values of the moment and the mass, the imbalance, the normal and tangential forces; the dependencies of the fluid pressure from some of the hydraulic parameters. The magnitude of the fluid pressure at the outlets of the pipelines is $30-50 \%$ from the inlet pressure.

Key words: an inlet, an outlet, fluid flow, a velocity, a local hydraulic resistance, a pressure, a pipeline.

Language: English

Citation: Chemezov D (2017) THE FINITE ELEMENT MODELING OF THE FLUID FLOW IN THE PIPELINES WITH THE COMPLEX LOCAL HYDRAULIC RESISTANCES. ISJ Theoretical \& Applied Science, 01 (45): 14-38.
Soi: http://s-o-i.org/1.1/TAS-01-45-4
Doi: crossef https://dx.doi.org/10.15863/TAS.2017.01.45.4

\section{Introduction}

On the straight section of the pipeline a process of the fluid flow has a steady character (laminar regime). Layers of the fluid are moved uniformly, relative to each other. The velocity of the fluid flow has a maximum at the centerline and minimum on the inner wall of the pipeline. The fluid pressure in the pipeline is changed opposite to the change of the flow velocity.

With a change of the pipeline sizes in a longitudinal or transverse cross sections, when the constant direction of the flow, the velocity of the fluid flow becomes variable. The deformation of the normal fluid flow with a change the direction and magnitude of average velocity is occurred [1]. To such simple local hydraulic resistances are belong the sudden expansion and contraction of the pipeline, diffusers and confusers [2, 3, 4].

With a change of the direction of the longitudinal axis of the pipeline and the velocity flow of fluid is observed the occurrence of the vortex flows. An intensive mixing of particles and the exchange of the momentum between the fluid particles is occurred. To such simple local hydraulic resistances are belong smooth or sharp turns of the pipeline (elbows) [5].

The complex resistance are comprised a combination of the several simple local hydraulic resistances in which the velocity vector changes in magnitude and direction. The calculation of pressure drop (velocity flow) in the complex local hydraulic resistances is causing difficulties when confluence or dividing a fluid flows in the channels of the pipeline. As a result of the sudden changes of direction and velocity of the fluid flow in the pipeline is occurred very significant deformation of the flow with the occurrence of the intense vortex. To such complex local hydraulic resistances are belong the union crosses, the tees, the gate valves, the globe valves and etc.

The mathematical calculation by the finite element method will allow to assess the character of the transient process of the fluid flow in the pipelines with the complex local hydraulic resistances and to select the branching, in which the least pressure drop is occurred.

\section{Materials and methods}

By the condition for the problem solution of the hydrodynamics was the fluid flow in the pipeline with the following complex local hydraulic resistances: the union cross (one inlet and three outlets), the tee (two inlets and one outlet), the tee (one inlet and two outlets).

The diameter of the channels for all pipelines on the inlet and outlet was taken the size of $20 \mathrm{~mm}$. 


\begin{tabular}{|c|c|c|c|c|c|c|}
\hline Impact Factor: & $\begin{array}{l}\text { ISRA (India) } \\
\text { ISI (Dubai, UAE } \\
\text { GIF (Australia) } \\
\text { JIF }\end{array}$ & $\begin{array}{l}=1.344 \\
=0.829 \\
=0.564 \\
=1.500\end{array}$ & $\begin{array}{l}\text { SIS (USA) } \\
\text { PИНЦ (Russia) } \\
\text { ESJI (KZ) } \\
\text { SJIF (Morocco) }\end{array}$ & $\begin{array}{l}=0.912 \\
=0.234 \\
=1.042 \\
=2.031\end{array}$ & $\begin{array}{l}\text { ICV (Poland) } \\
\text { PIF (India) } \\
\text { IBI (India) }\end{array}$ & $\begin{array}{l}=6.630 \\
=1.940 \\
=4.260\end{array}$ \\
\hline
\end{tabular}

The length of the channels before and after the local hydraulic resistance was taken the size of $50 \mathrm{~mm}$.

The union cross represents an intersection of the two pipelines at 90 degrees with the formation of the four channels for direction of the fluid flow. The angle between the two outlet channels of the tee was adopted a value of 50 degrees.

Three-dimensional solid models of the complex local hydraulic resistances and the schemes of the fluid flow in them are presented in Fig. 1.

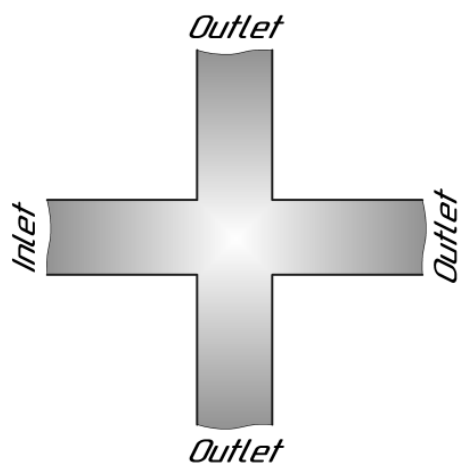

a)

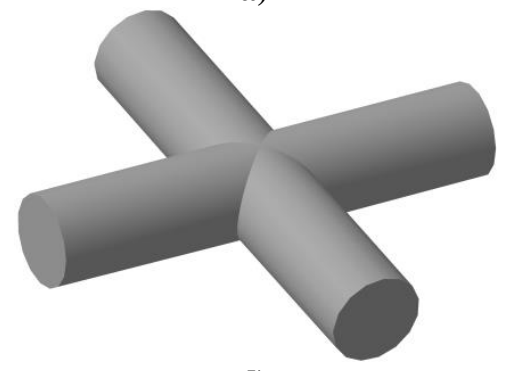

d)

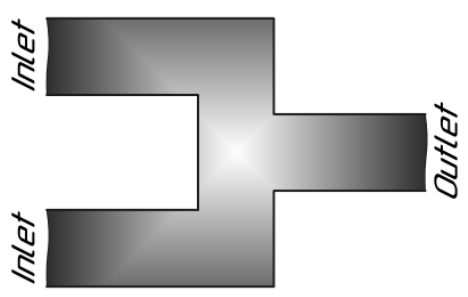

b)

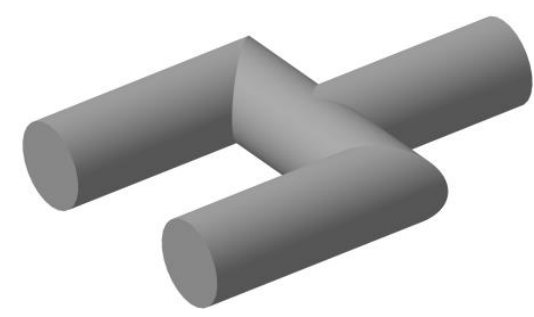

e)

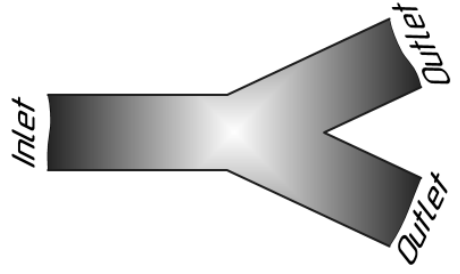

c)

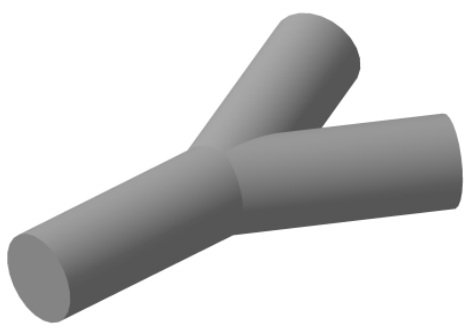

f)

Figure 1 - Complex local hydraulic resistance: $a$ - the scheme of the fluid flow in the union cross; $b, c-t h e$ first and second schemes of the fluid flow in the tees; $d$ - the three-dimensional model of the union cross; $e, f$ - the first and second three-dimensional models of the tees.

Computer simulation of the fluid flow in the pipelines with the local hydraulic resistances was performed based on the finite element method in CFX module of the Ansys Workbench program. For implementation of the problem solution of the hydrodynamics the solid models of fragments of the pipelines with the local resistances were partitioned into finite elements (mesh). The size of one element is accepted by the value of $1 \mathrm{~mm}$.

Water at $25{ }^{\circ} \mathrm{C}$ is selected as the simulated liquid. The density of water at a given temperature [6] is $997 \mathrm{~kg} / \mathrm{m}^{3}$, the molar mass - $18.02 \mathrm{~g} / \mathrm{mol}$, the specific heat capacity at the constant pressure $4181.7 \mathrm{~J} /(\mathrm{kg} \cdot \mathrm{K})$, the dynamic viscosity -0.0008899 $\mathrm{kg} /(\mathrm{m} \cdot \mathrm{s})$, the thermal conductivity - 0.6069 $\mathrm{W} /(\mathrm{m} \cdot \mathrm{K})$, the refractive index -1 , the thermal expansivity $-0.000257 \mathrm{~K}$. On models were acted the reference pressure (1 atm).

When steady state and a continuous fluid were set the initial conditions of the simulation on the inlets and outlets of the pipelines:

1. At the inlet (Boundary 1) - subsonic regime of the fluid flow with a normal speed of $1.5 \mathrm{~m} / \mathrm{s}$ and a thermal radiation taken by the local temperature. The turbulence was determined by the eddy viscosity ratio.
2. At the outlet (Boundary 2) - subsonic regime of the fluid flow with a thermal radiation taken by the local temperature.

No slip of the fluid on the inner walls of the pipelines was installed for the Boundary 3 under the following conditions of the thermal radiation: the emissivity -1 , the diffuse fraction -1 . The opaque smooth wall of the pipelines is used [7,8].

For calculation it was used the thermal radiation model Monte Carlo with a number of histories of 10000 [9]. The radiation transfer mode participating media.

The turbulent fluid flow was calculated on the basis of the adopted turbulence model BSL Reynolds stress [10].

The components of the flow velocity, the intensity of the thermal radiation and static pressure on the inlet of the numerical automatically are calculated when start of the calculation problem. The initial conditions of the turbulent fluid flow were taken by according to the k-omega model.

The results of the numerical calculation problem of hydraulics were obtained by following the given parameters: extra output variables list absolute pressure; file compression level - best speed least compression; turbulence numerics and advection scheme [11] - high resolution; body force

ISPC Perspectives in science for 2017, 
averaging type - arithmetic; length scale option conservative; maximum number of iterations -100 ; minimum number of iterations - 1.0; timescale factor -1.0 ; conservation target -0.01 ; residual target 0.0001 ; residual type - RMS; pressure and velocity interpolation type - trilinear; shape function option geometric; Rhie-Chow option [12] - high resolution; partitioning type - optimized recursive coordinate bisection; start method - serial.

\section{Results and discussion}

A visual display of the flow velocity in the local hydraulic resistances of the pipelines is presented in Fig. 2.

For a more detailed presentation of the process of the fluid flow in a three-dimensional setting was set to 250 streamlines of the flow in the cross-section of inlet and outlet channels of the pipelines.

For the union cross and the tee with two outputs, the velocity of the fluid flow to dividing flow is increased by $42 \%$ and $22 \%$ respectively. Herewith a laminar regime of the fluid flow is not saved. The fluid motion in the transverse channels of the union cross causes the deformation of the flow. The fluid flow fills the volume of the transverse channels on $35 \%$. In the longitudinal channel of the union cross the flow velocity is reduced in 4 times. When the dividing flow in the tee, subject to the change of the direction and the reduction of the velocity of the fluid flow in 2 times, turbulent regime is not observed.

The confluence of two flows in the transverse channel of the tee with one outlet leads to the formation of a turbulent regime of the fluid flow. In the output channel is created maximum velocity of the fluid flow and, respectively, the greatest pressure drop.

The dependencies of RMS values of the mass and the moment components of the fluid motion in the pipelines with the local hydraulic resistances from time step of the solution are presented in Fig. 3 . The dependencies of the thermal radiation, the mass, the moment components, the turbulence frequency and the Reynolds stress at the inlet and outlet of the pipelines with the local hydraulic resistances and in conditions of the near wall flow from time step of the solution are presented in Fig. $4-6$. The dependencies of an imbalance of the thermal radiation, the mass and the moment components of the fluid motion in the pipelines with the local hydraulic resistances (in the percentage) from time step of the solution are presented in Fig. 7. The dependencies of the normal and tangential forces and moments during the fluid flow in the pipelines with the local hydraulic resistances from time step of the solution are presented in Fig. 8 - 11 .

The RMS value of the mass of the fluid motion (RMS P-Mass) in all pipelines is almost the same.
The moment components of the fluid motion (RMS U-Mom, RMS V-Mom, RMS W-Mom) at the beginning of the problem solution (at inlet) have different values, and in the end the solution (at outlet) parameters have the same values.

When comparing of the character of the fluid flow at inlets, outlets and on the internal walls of the pipelines can be noted that thermal radiation (IRadiation) in the tee with two outlets has a greater intensity than in other local resistances. Stepwise changes of the components of the Reynolds stress (uu-RS, uw-RS, vw-RS, uv-RS, vv-RS, ww-RS) are occurred in outlet channel of the tee.

The imbalance of the mass of the fluid motion in the union cross and the tee with one outlet exceeds of $80 \%$. The component of the moment U-Mom of the fluid motion in the union cross has the greatest imbalance in the beginning and on the subsequent steps of the problem solution.

The force acting on the wall surface of the pipelines is decomposed into two components normal and tangential. The components of the normal force during fluid flow in the tee with one outlet are the largest to order than in the tee with two outlets. The components of the tangential force during fluid flow in the tee with two outlets are not changed in the magnitude.

The chaotic fluid motion on the some sections of the union cross and the tee with one outlet leads to varying values (increasing and decreasing) of the normal and tangential moments. The magnitudes of the normal and tangential moments are changed slightly, including in the zone of dividing of the fluid flow.

The dependencies of the eddy viscosity, the radiation intensity, the turbulence eddy frequency, the flow velocity from the fluid pressure in the pipelines with the local hydraulic resistances are presented in Fig. $12-21$.

With the same initial conditions of the process of the fluid flow in the pipelines with the complex local hydraulic resistances the pressure in the channels will be both positive and negative. Herewith in the union cross and the tee with two outlets where the fluid flow has steady state, the negative pressure acts. In the tee with one outlet a positive pressure acts (turbulent regime of the fluid flow under the significant deformation of the flow).

The fluid pressure at the different sections of the channels of the pipeline will change over time. By that we can explain the difficult nonlinear dependencies.

Let me explain the changing of the values of the hydraulic characteristics of the fluid flow at negative and positive pressures.

The greatest value of the eddy viscosity in the laminar flow is observed at a negative pressure and in the turbulent flow - at a positive pressure. 


\begin{tabular}{l|lr|ll|ll} 
& ISRA (India) & $=\mathbf{1 . 3 4 4}$ & SIS (USA) & $=\mathbf{0 . 9 1 2}$ & ICV (Poland) & $=\mathbf{6 . 6 3 0}$ \\
Impact Factor: & ISI (Dubai, UAE) $=\mathbf{0 . 8 2 9}$ & PVHL (Russia) & $=\mathbf{0 . 2 3 4}$ & PIF (India) & $=\mathbf{1 . 9 4 0}$ \\
& GIF (Australia) & $=\mathbf{0 . 5 6 4}$ & ESJI (KZ) & $=\mathbf{1 . 0 4 2}$ & IBI (India) & $=\mathbf{4 . 2 6 0}$ \\
& JIF & $\mathbf{1 . 5 0 0}$ & SJIF (Morocco) & $\mathbf{2 . 0 3 1}$ & & \\
\hline
\end{tabular}

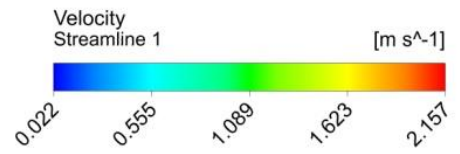

a)

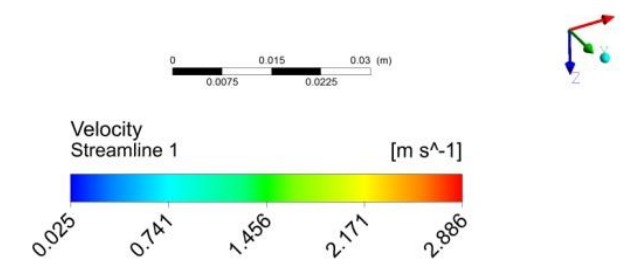

b)

c)

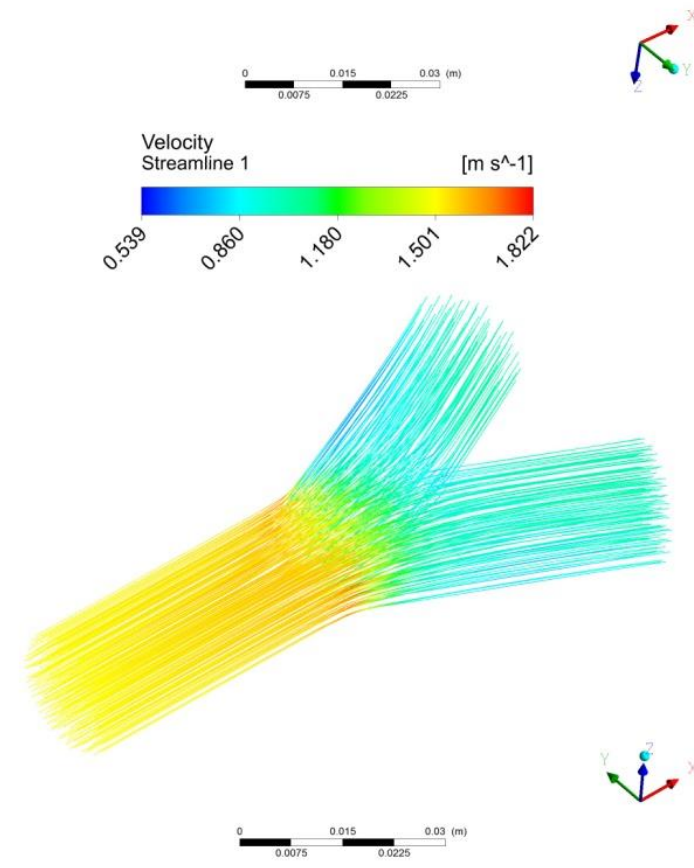

Figure 2 - Velocity change of the fluid flow: $a$ - in the union cross; $b, c$ - in the tees (the model No.1 and No.2). 


\begin{tabular}{l|lrl|l|ll} 
& ISRA (India) & $=\mathbf{1 . 3 4 4}$ & SIS (USA) & $=\mathbf{0 . 9 1 2}$ & ICV (Poland) & $=\mathbf{6 . 6 3 0}$ \\
Impact Factor: & ISI (Dubai, UAE) $=\mathbf{0 . 8 2 9}$ & PUHU (Russia) $=\mathbf{0 . 2 3 4}$ & PIF (India) & $=\mathbf{1 . 9 4 0}$ \\
& GIF (Australia) & $\mathbf{0 . 5 6 4}$ & ESJI (KZ) & $=\mathbf{1 . 0 4 2}$ & IBI (India) & $\mathbf{4 . 2 6 0}$
\end{tabular}

a)

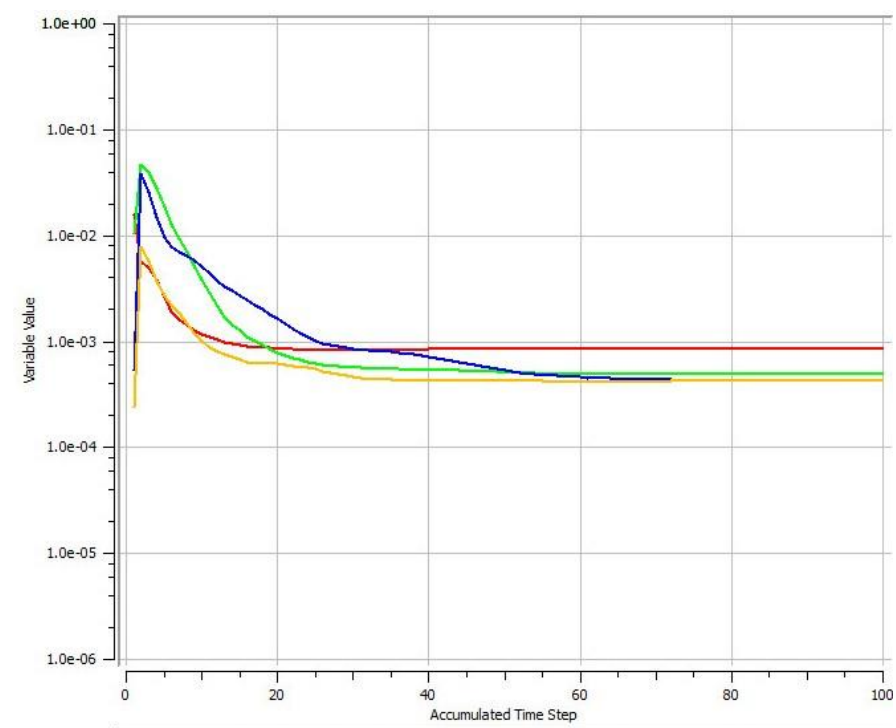

b)

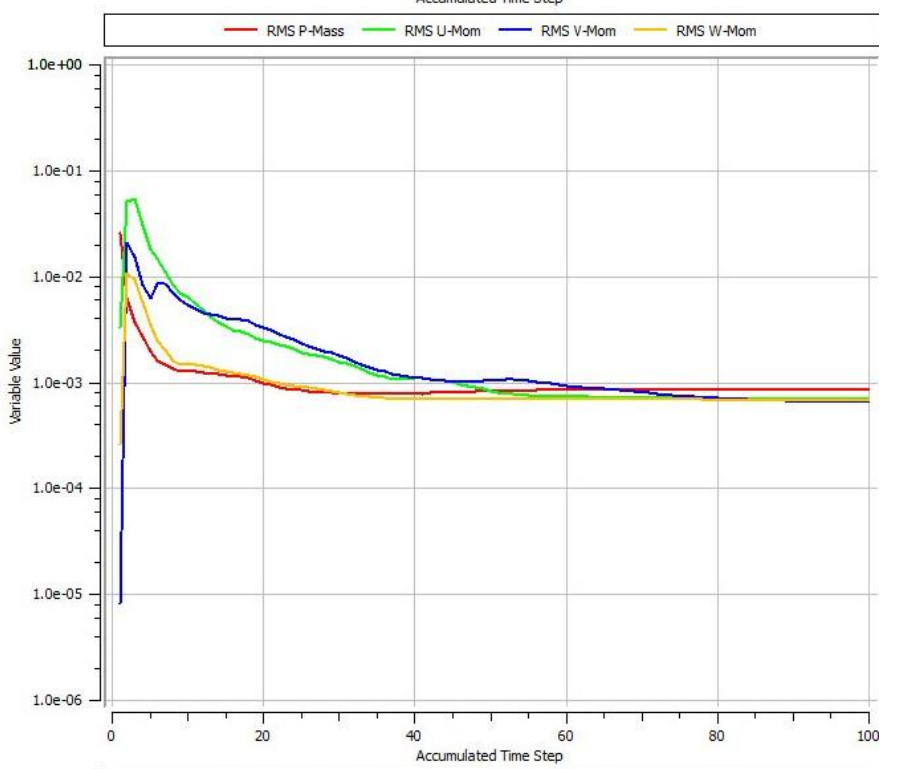

c)

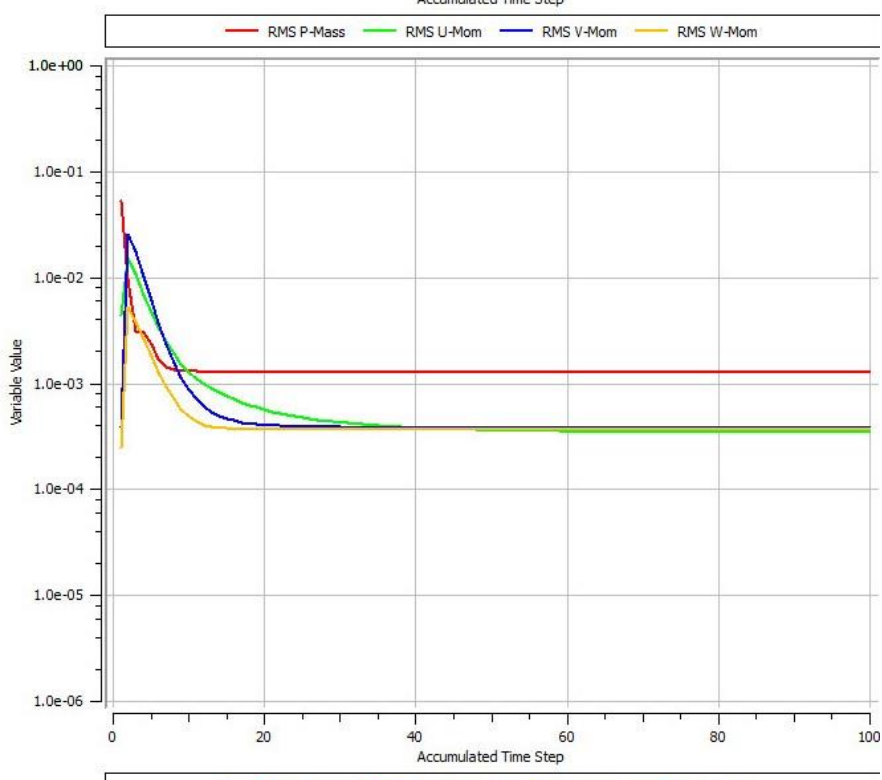

- RMS P.Mass - RMS U-Mom - RMS V-Mom - RMS W-Mom

Figure 3 - The dependencies of RMS values of the mass and the moment components of the fluid motion from time step of the solution: a - the union cross; $b$ - the tee (model No. 1); $c$ - the tee (model No. 2).

ISPC Perspectives in science for 2017, 


\begin{tabular}{|c|c|c|c|c|c|c|}
\hline Impact Factor: & $\begin{array}{l}\text { ISRA (India) } \\
\text { ISI (Dubai, UAE } \\
\text { GIF (Australia) } \\
\text { JIF }\end{array}$ & $\begin{array}{l}=1.344 \\
=0.829 \\
=0.564 \\
=1.500\end{array}$ & $\begin{array}{l}\text { SIS (USA) } \\
\text { PИНЦ (Russia) } \\
\text { ESJI (KZ) } \\
\text { SJIF (Morocco) }\end{array}$ & $\begin{array}{l}=0.912 \\
=0.234 \\
=1.042 \\
=2.031\end{array}$ & $\begin{array}{l}\text { ICV (Poland) } \\
\text { PIF (India) } \\
\text { IBI (India) }\end{array}$ & $\begin{array}{l}=6.630 \\
=1.940 \\
=4.260\end{array}$ \\
\hline
\end{tabular}

a)
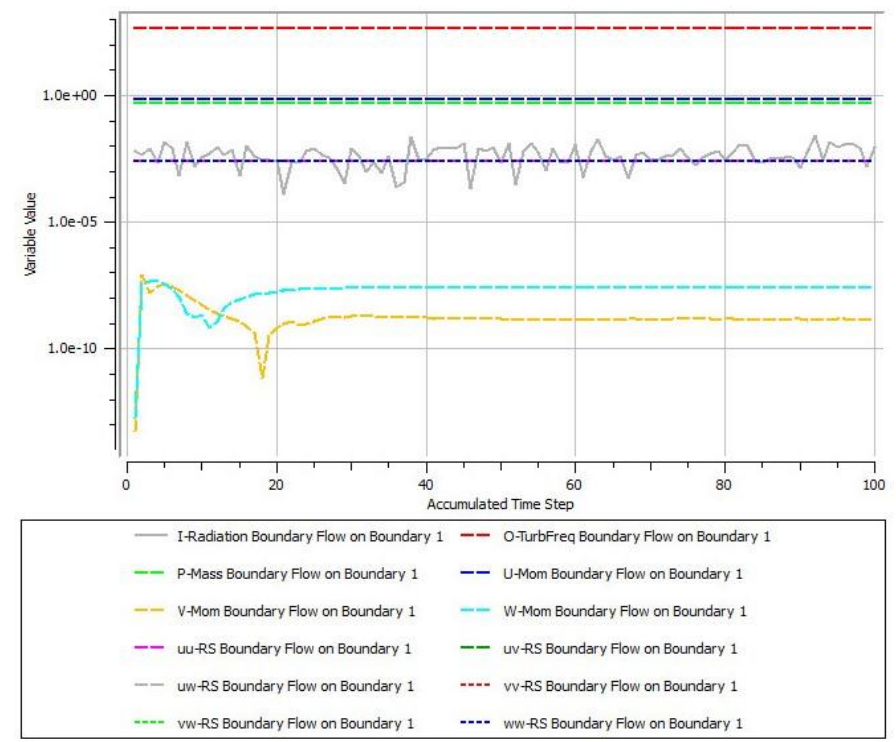

b)

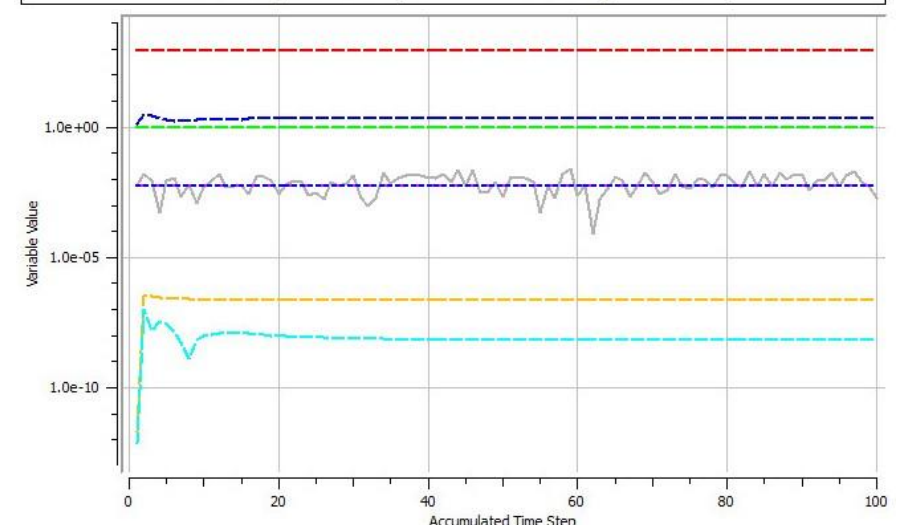

Accumulated Time Step

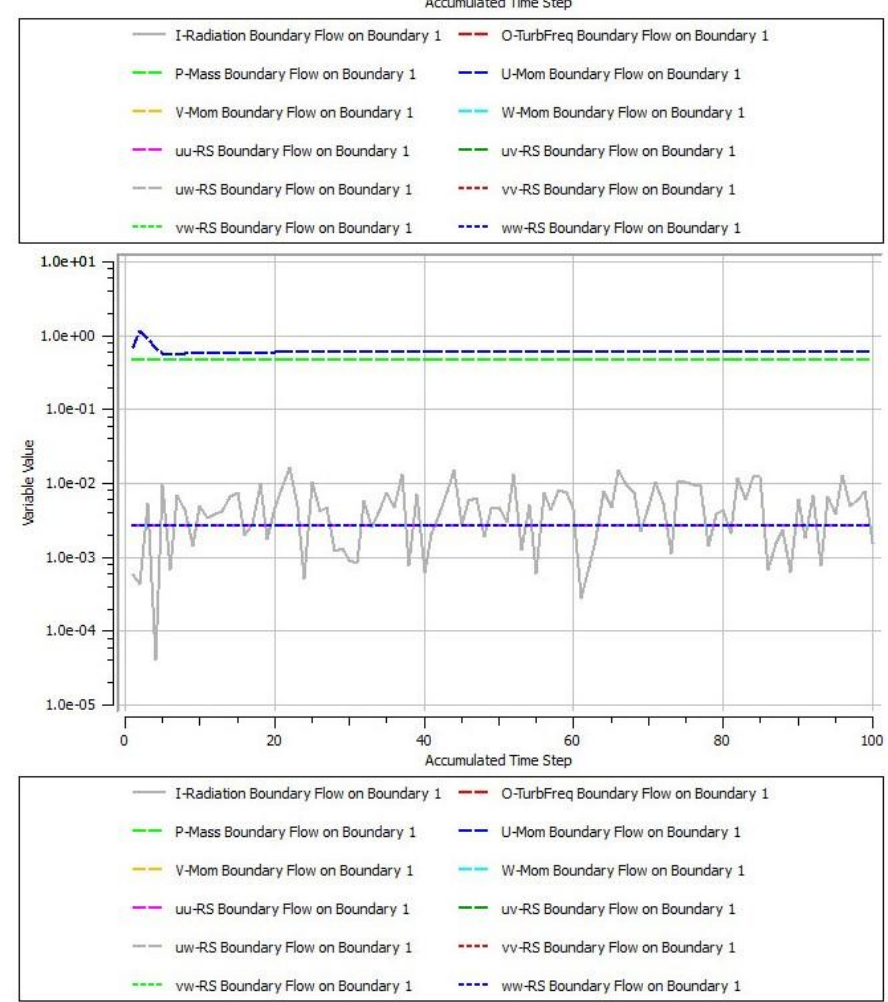

c)

Figure 4 - The dependencies of the some parameters (the thermal radiation, the mass, the moment components, the turbulence frequency and the Reynolds stress) of the fluid flow on the boundary 1 from time step of the solution: $a$ - the union cross; $b$ - the tee (model No. 1); $c$ - the tee (model No. 2).

ISPC Perspectives in science for 2017 , 


\begin{tabular}{l|lrl|l|ll} 
& ISRA (India) & $=\mathbf{1 . 3 4 4}$ & SIS (USA) & $=\mathbf{0 . 9 1 2}$ & ICV (Poland) & $=\mathbf{6 . 6 3 0}$ \\
Impact Factor: & ISI (Dubai, UAE) $=\mathbf{0 . 8 2 9}$ & PUHU (Russia) $=\mathbf{0 . 2 3 4}$ & PIF (India) & $=\mathbf{1 . 9 4 0}$ \\
& GIF (Australia) & $\mathbf{0 . 5 6 4}$ & ESJI (KZ) & $=\mathbf{1 . 0 4 2}$ & IBI (India) & $\mathbf{4 . 2 6 0}$
\end{tabular}

a)
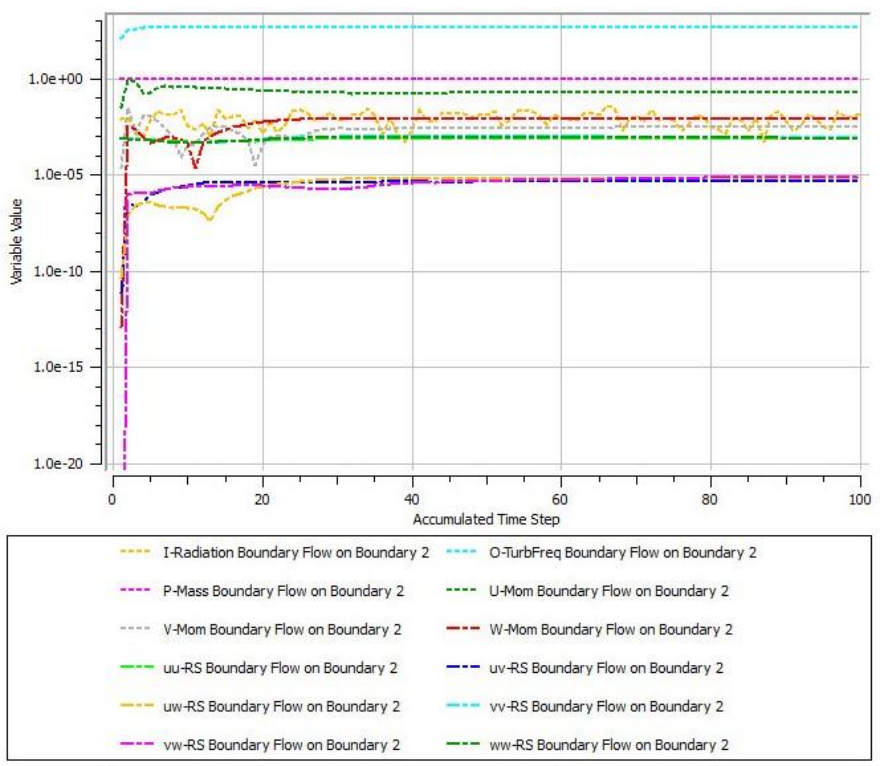

b)
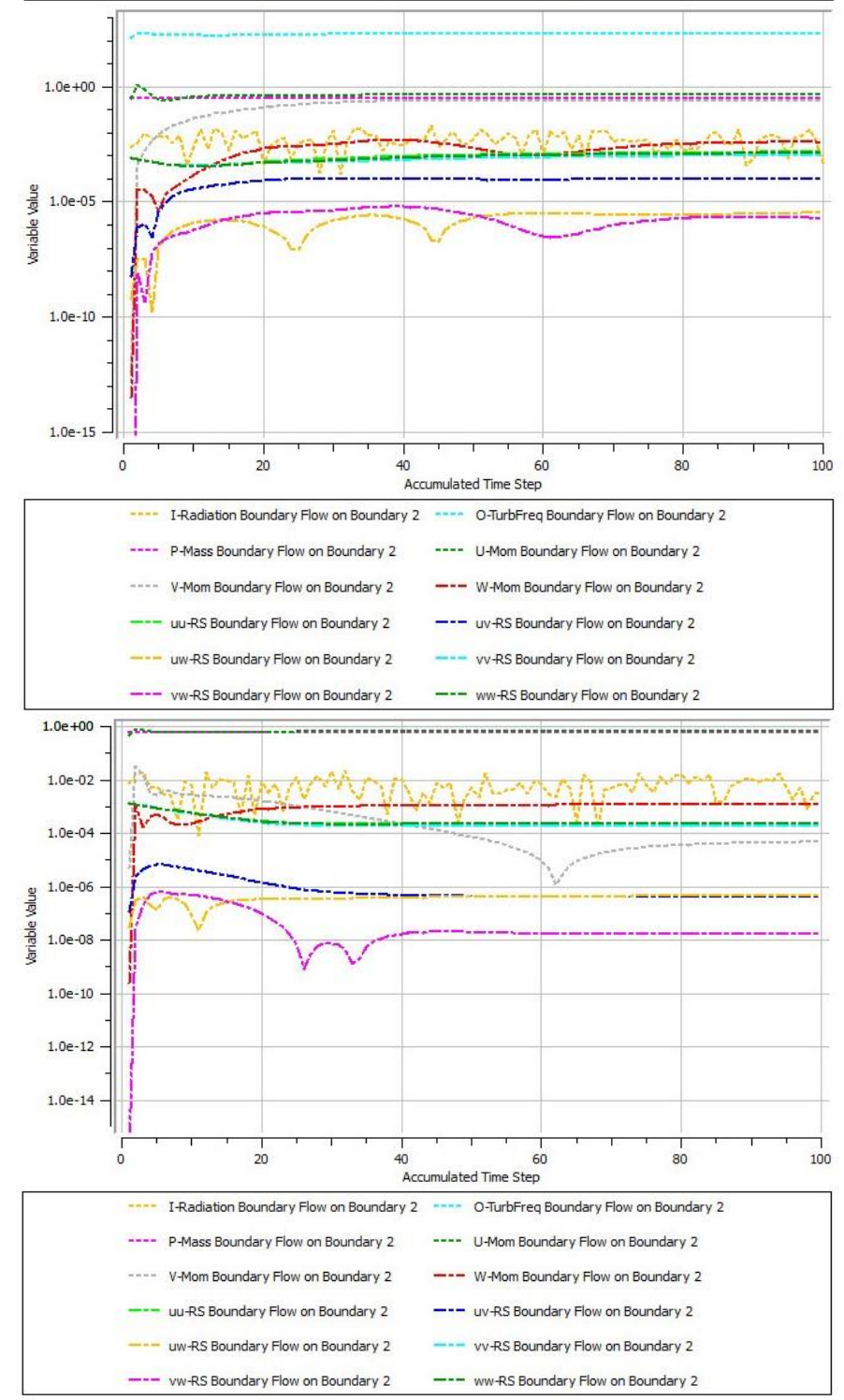

Figure 5 - The dependencies of the some parameters (the thermal radiation, the mass, the moment components, the turbulence frequency and the Reynolds stress) of the fluid flow on the boundary 2 from time step of the solution: $a$ - the union cross; $b$ - the tee (model No. 1); $c$ - the tee (model No. 2).

ISPC Perspectives in science for 2017, 


\begin{tabular}{l|lrl|l|ll} 
& ISRA (India) & $=\mathbf{1 . 3 4 4}$ & SIS (USA) & $=\mathbf{0 . 9 1 2}$ & ICV (Poland) & $=\mathbf{6 . 6 3 0}$ \\
Impact Factor: & ISI (Dubai, UAE) $=\mathbf{0 . 8 2 9}$ & PUHU (Russia) $=\mathbf{0 . 2 3 4}$ & PIF (India) & $=\mathbf{1 . 9 4 0}$ \\
& GIF (Australia) & $\mathbf{0 . 5 6 4}$ & ESJI (KZ) & $=\mathbf{1 . 0 4 2}$ & IBI (India) & $\mathbf{4 . 2 6 0}$
\end{tabular}

a)
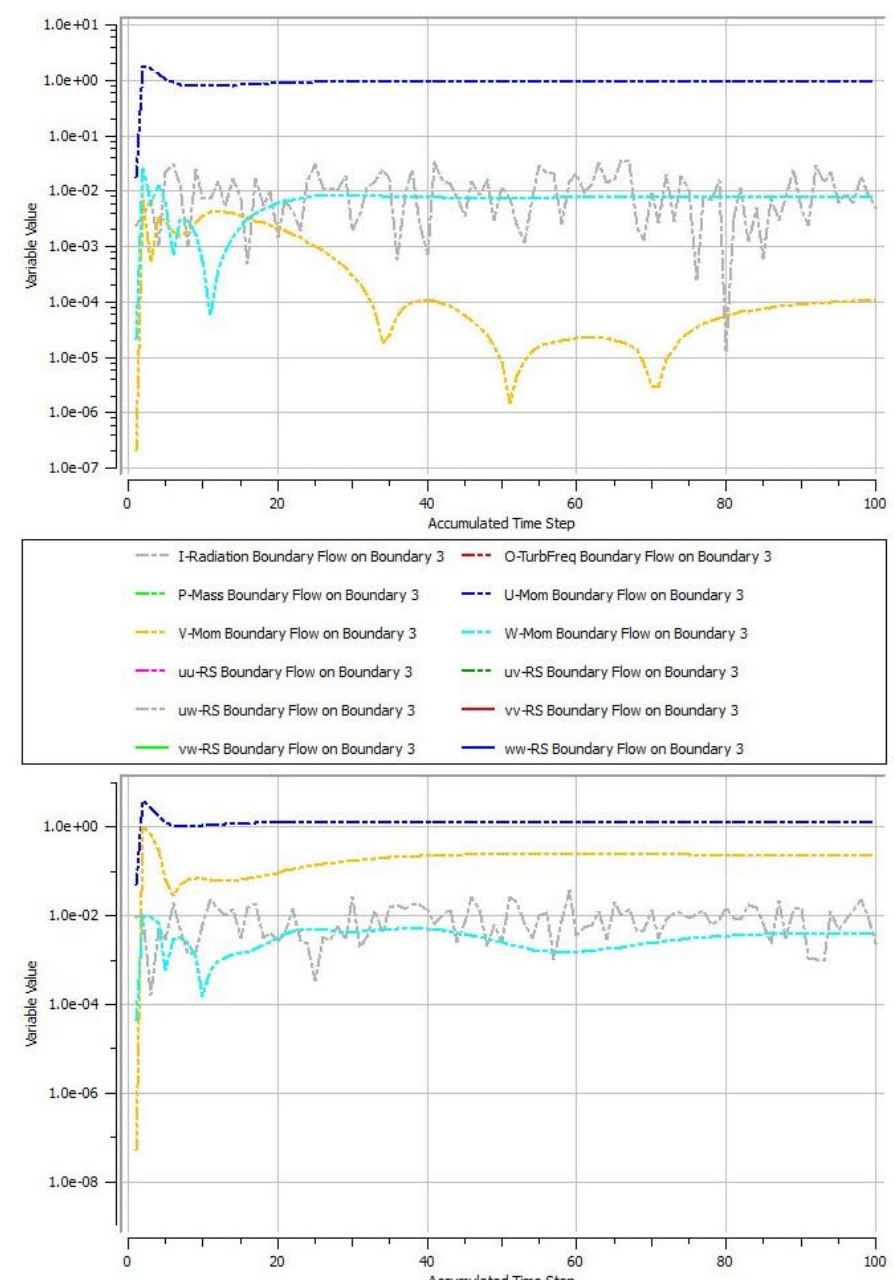

b)

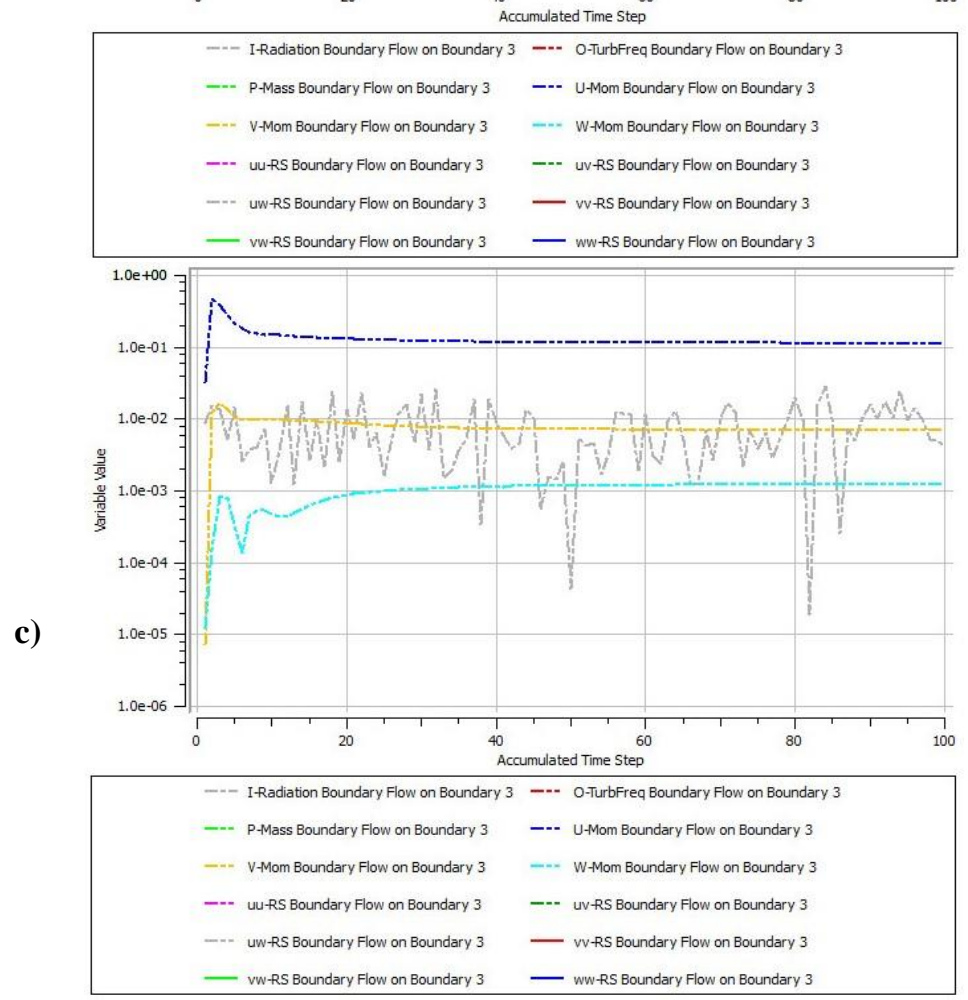

Figure 6 - The dependencies of the some parameters (the thermal radiation, the mass, the moment components, the turbulence frequency and the Reynolds stress) of the fluid flow on the boundary 3 from time step of the solution: $a$ - the union cross; $b$ - the tee (model No. 1); $c$ - the tee (model No. 2).

ISPC Perspectives in science for 2017, 


\begin{tabular}{l|lrl|l|ll} 
& ISRA (India) & $=\mathbf{1 . 3 4 4}$ & SIS (USA) & $=\mathbf{0 . 9 1 2}$ & ICV (Poland) & $=\mathbf{6 . 6 3 0}$ \\
Impact Factor: & ISI (Dubai, UAE) $=\mathbf{0 . 8 2 9}$ & PUHU (Russia) $=\mathbf{0 . 2 3 4}$ & PIF (India) & $=\mathbf{1 . 9 4 0}$ \\
& GIF (Australia) & $\mathbf{0 . 5 6 4}$ & ESJI (KZ) & $=\mathbf{1 . 0 4 2}$ & IBI (India) & $\mathbf{4 . 2 6 0}$
\end{tabular}

a)
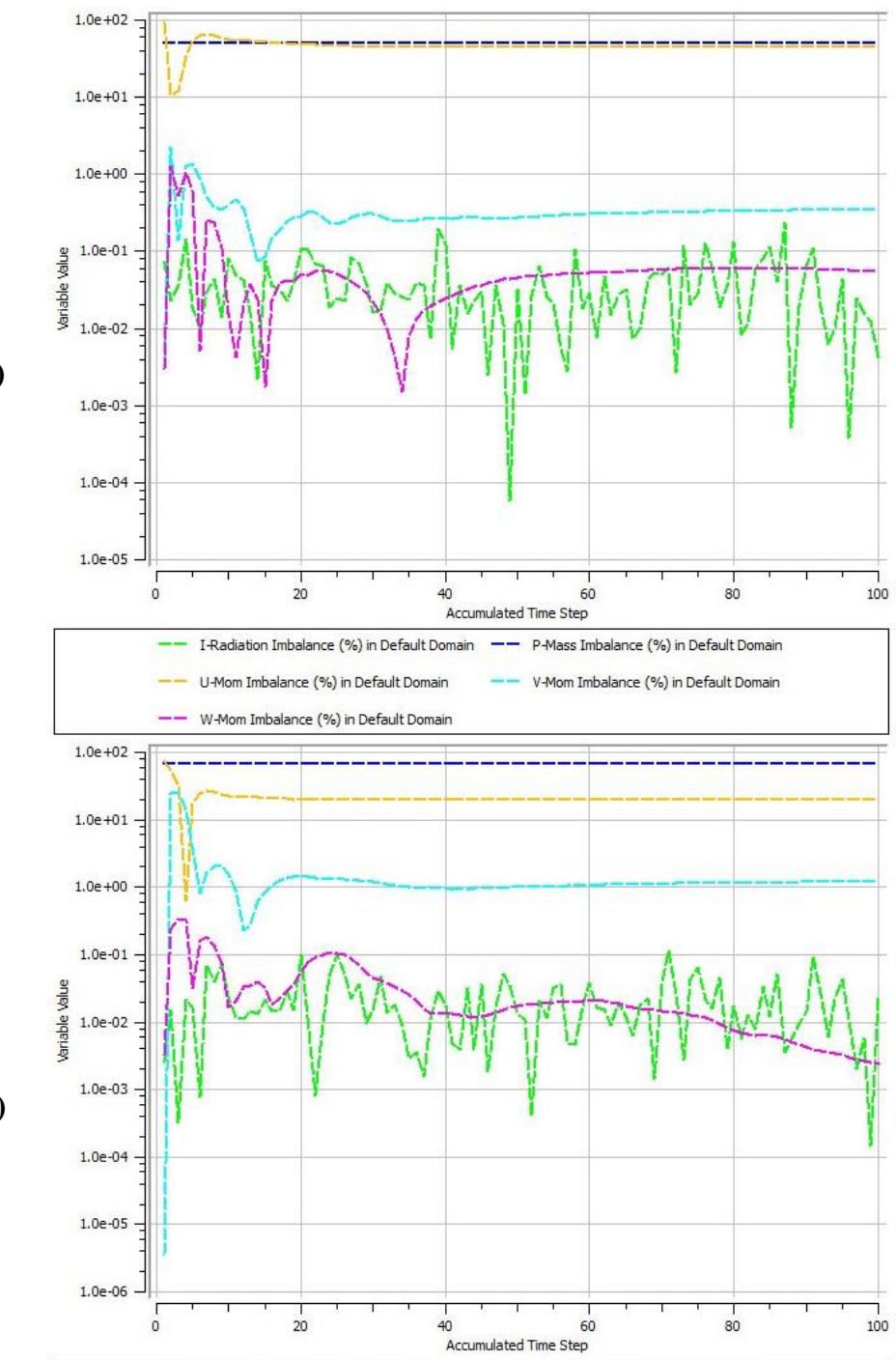

b)

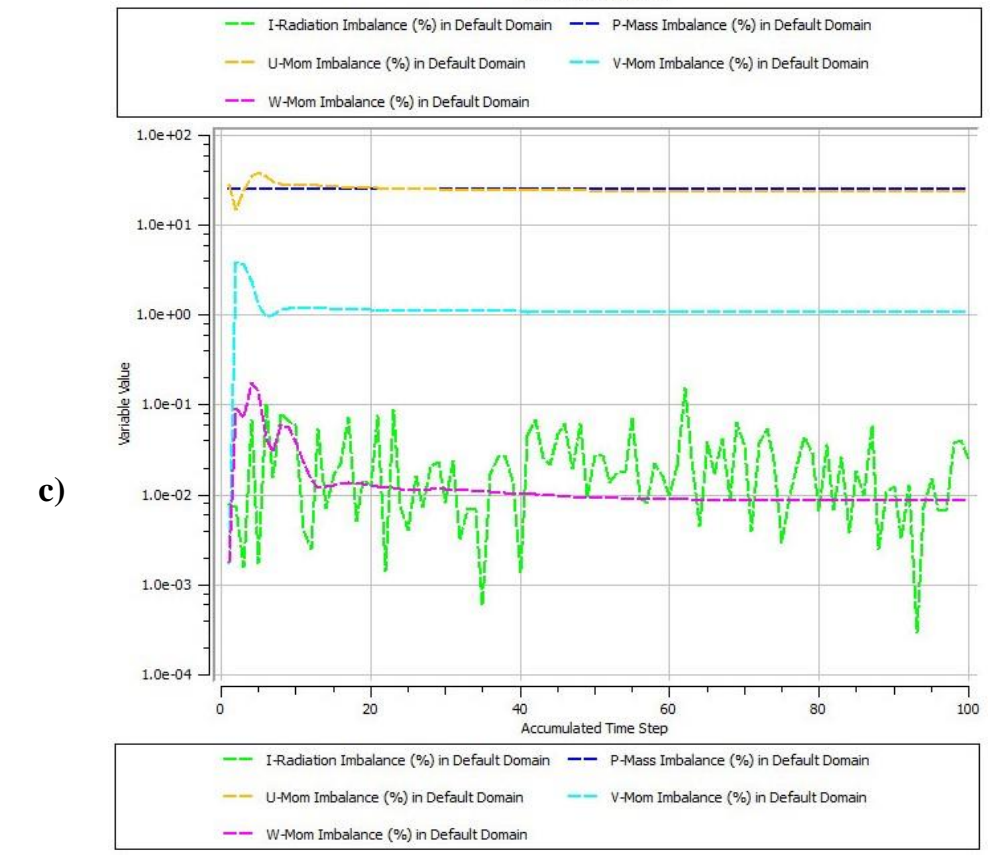

Figure 7 - The dependencies of an imbalance of the thermal radiation, the mass and the moment components of the fluid motion in the percentage from time step of the solution: $a$ - the union cross; $b$ - the tee (model No. 1); $\mathrm{c}$ - the tee (model No. 2).

ISPC Perspectives in science for 2017, 


\begin{tabular}{l|lrl|l|ll} 
& ISRA (India) & $=\mathbf{1 . 3 4 4}$ & SIS (USA) & $=\mathbf{0 . 9 1 2}$ & ICV (Poland) & $=\mathbf{6 . 6 3 0}$ \\
Impact Factor: & ISI (Dubai, UAE) $=\mathbf{0 . 8 2 9}$ & PUHL (Russia) $=\mathbf{0 . 2 3 4}$ & PIF (India) & $=\mathbf{1 . 9 4 0}$ \\
& GIF (Australia) & $\mathbf{0 . 5 6 4}$ & ESJI (KZ) & $=\mathbf{1 . 0 4 2}$ & IBI (India) & $=\mathbf{4 . 2 6 0}$ \\
& JIF & $\mathbf{1 . 5 0 0}$ & SJIF (Morocco) & $=\mathbf{2 . 0 3 1}$ & & \\
\hline
\end{tabular}

a)

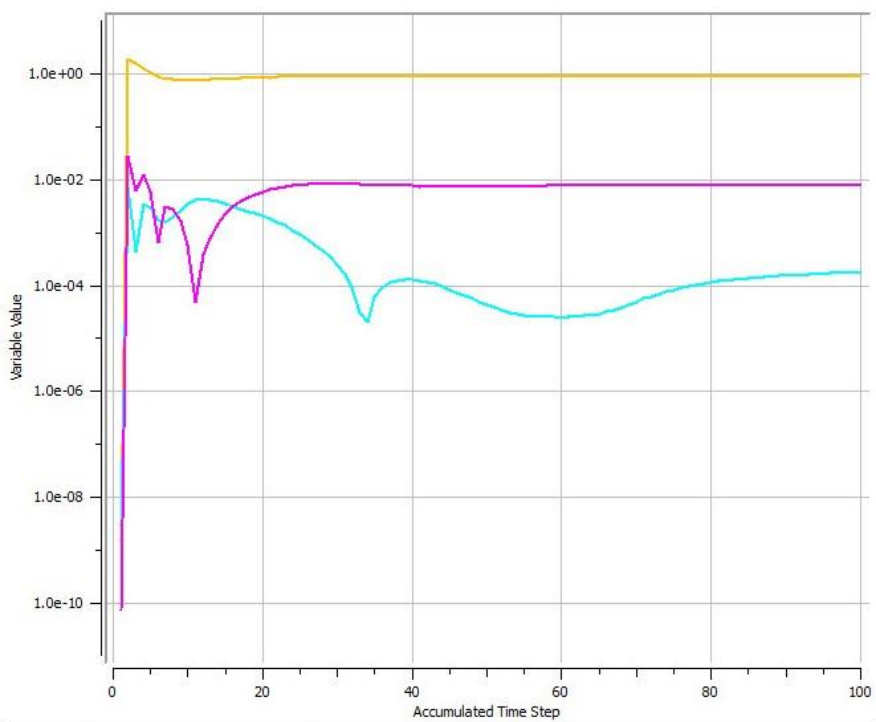

- Normal Force on Boundary $3(x)$ - Normal Force on Boundary $3(m)$ - Normal Force on Boundary $3(z)$

b)
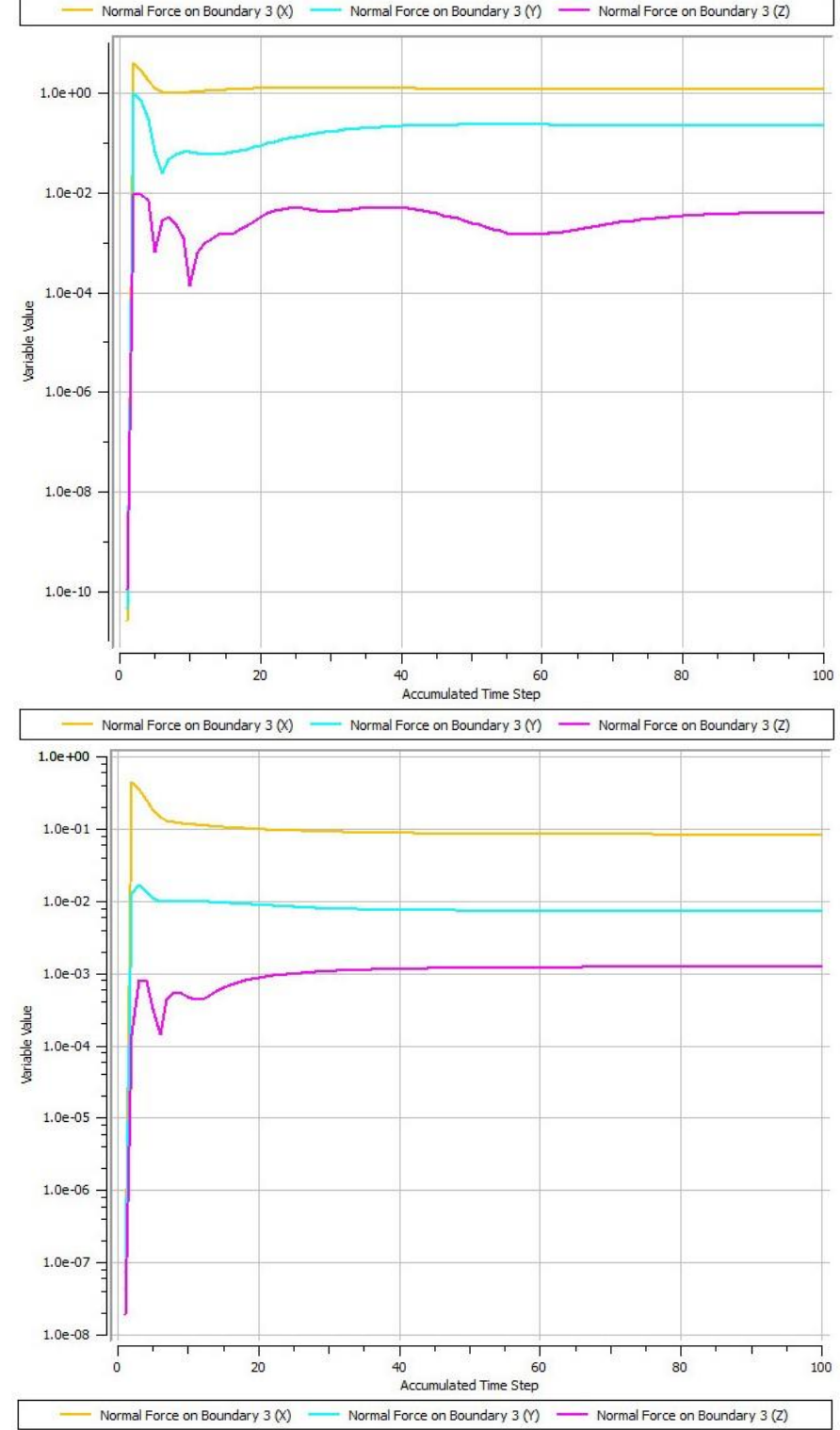

Figure 8 - The dependencies of the normal force (on the three coordinate axes) during the fluid flow on the boundary 3 from time step of the solution: a - the union cross; $b$ - the tee (model No. 1); $c$ - the tee (model No. 2).

ISPC Perspectives in science for 2017, 


\begin{tabular}{|c|c|c|c|c|c|c|}
\hline Impact Factor: & $\begin{array}{l}\text { ISRA (India) } \\
\text { ISI (Dubai, UAE } \\
\text { GIF (Australia) } \\
\text { JIF }\end{array}$ & $\begin{array}{l}=1.344 \\
=0.829 \\
=0.564 \\
=1.500\end{array}$ & $\begin{array}{l}\text { SIS (USA) } \\
\text { PИНЦ (Russia) } \\
\text { ESJI (KZ) } \\
\text { SJIF (Morocco) }\end{array}$ & $\begin{array}{l}=0.912 \\
=0.234 \\
=1.042 \\
=2.031\end{array}$ & $\begin{array}{l}\text { ICV (Poland) } \\
\text { PIF (India) } \\
\text { IBI (India) }\end{array}$ & $\begin{array}{l}=6.630 \\
=1.940 \\
=4.260\end{array}$ \\
\hline
\end{tabular}

a)
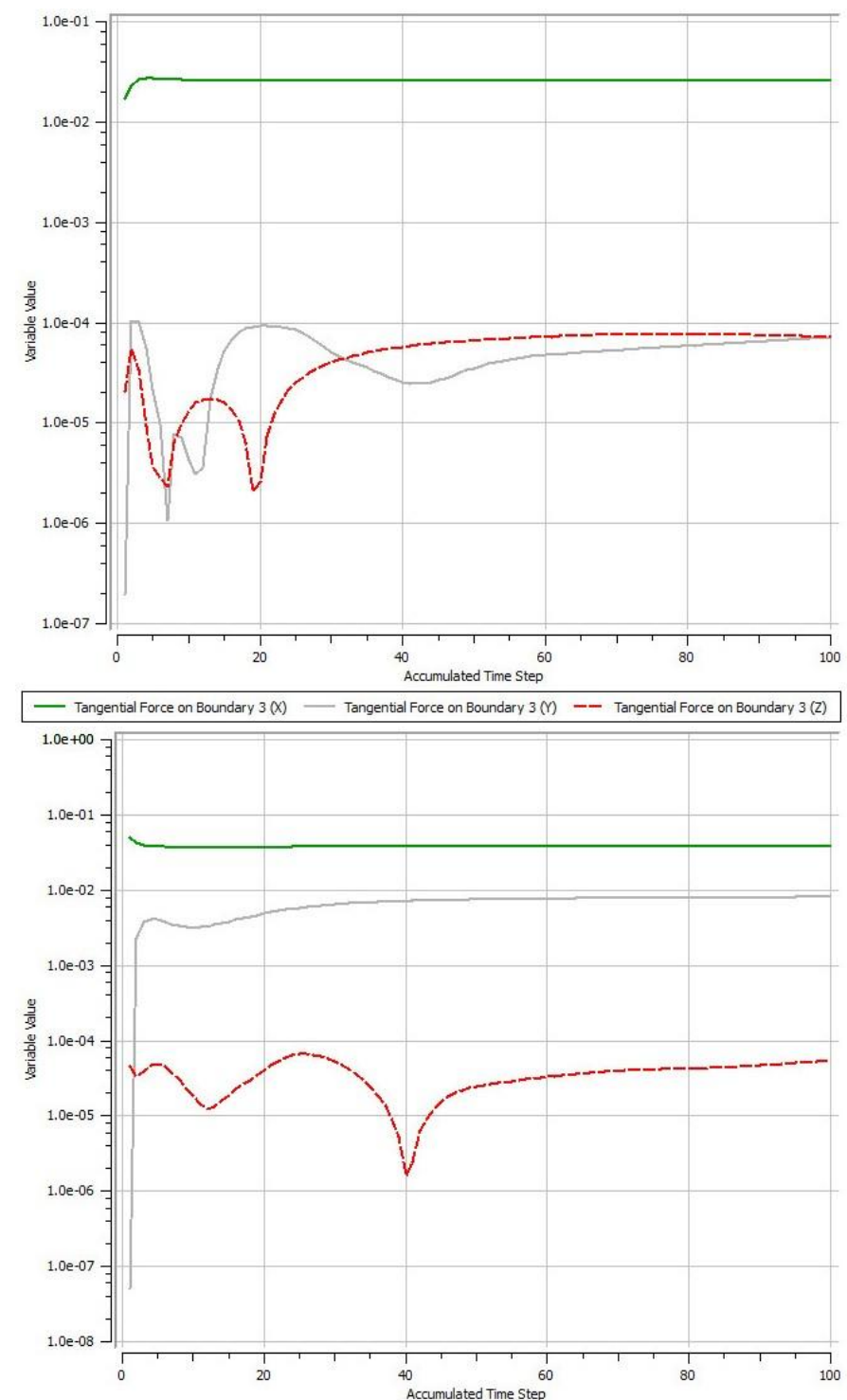

b)

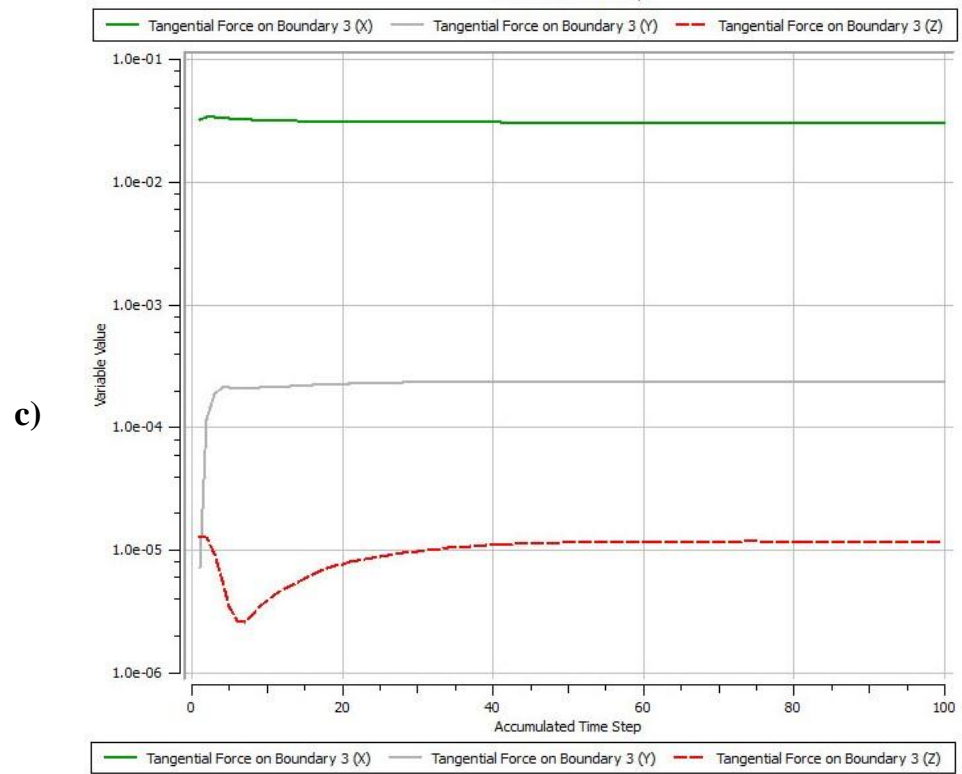

Figure 9 - The dependencies of the tangential force (on the three coordinate axes) during the fluid flow on the boundary 3 from time step of the solution: $a$ - the union cross; $b$ - the tee (model No. 1); $c$ - the tee (model No. 2).

ISPC Perspectives in science for 2017, 


\begin{tabular}{l|lrl|l|ll} 
& ISRA (India) & $=\mathbf{1 . 3 4 4}$ & SIS (USA) & $=\mathbf{0 . 9 1 2}$ & ICV (Poland) & $=\mathbf{6 . 6 3 0}$ \\
Impact Factor: & ISI (Dubai, UAE) $=\mathbf{0 . 8 2 9}$ & PUHL (Russia) $=\mathbf{0 . 2 3 4}$ & PIF (India) & $=\mathbf{1 . 9 4 0}$ \\
& GIF (Australia) & $\mathbf{0 . 5 6 4}$ & ESJI (KZ) & $=\mathbf{1 . 0 4 2}$ & IBI (India) & $=\mathbf{4 . 2 6 0}$ \\
& JIF & $\mathbf{1 . 5 0 0}$ & SJIF (Morocco) & $=\mathbf{2 . 0 3 1}$ & & \\
\hline
\end{tabular}

a)

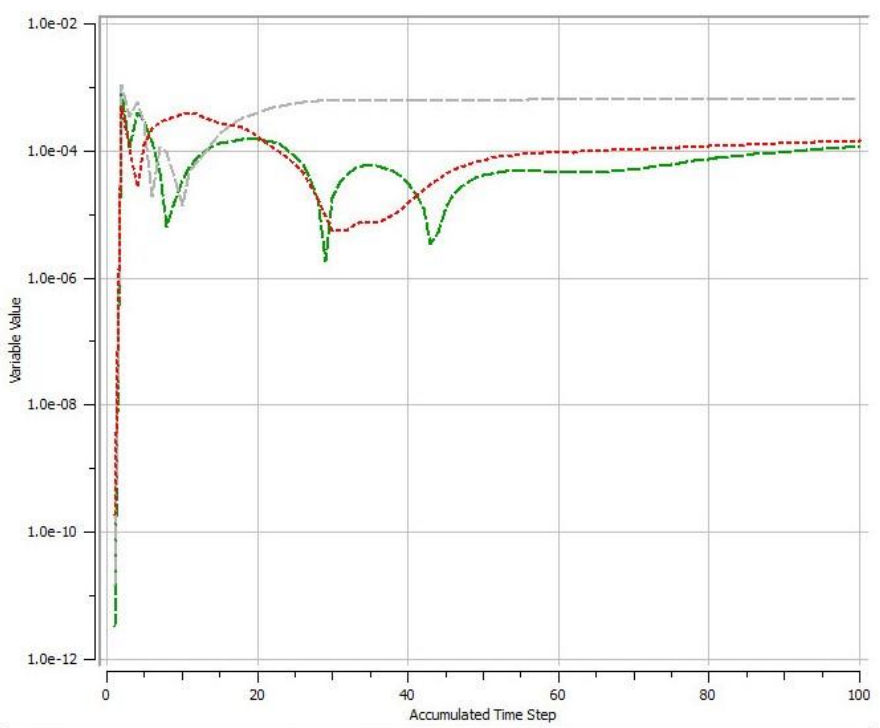

-- Normal Moment on Boundary $3(x) \quad--$ Normal Moment on Boundary $3(\eta) \cdots$

b)
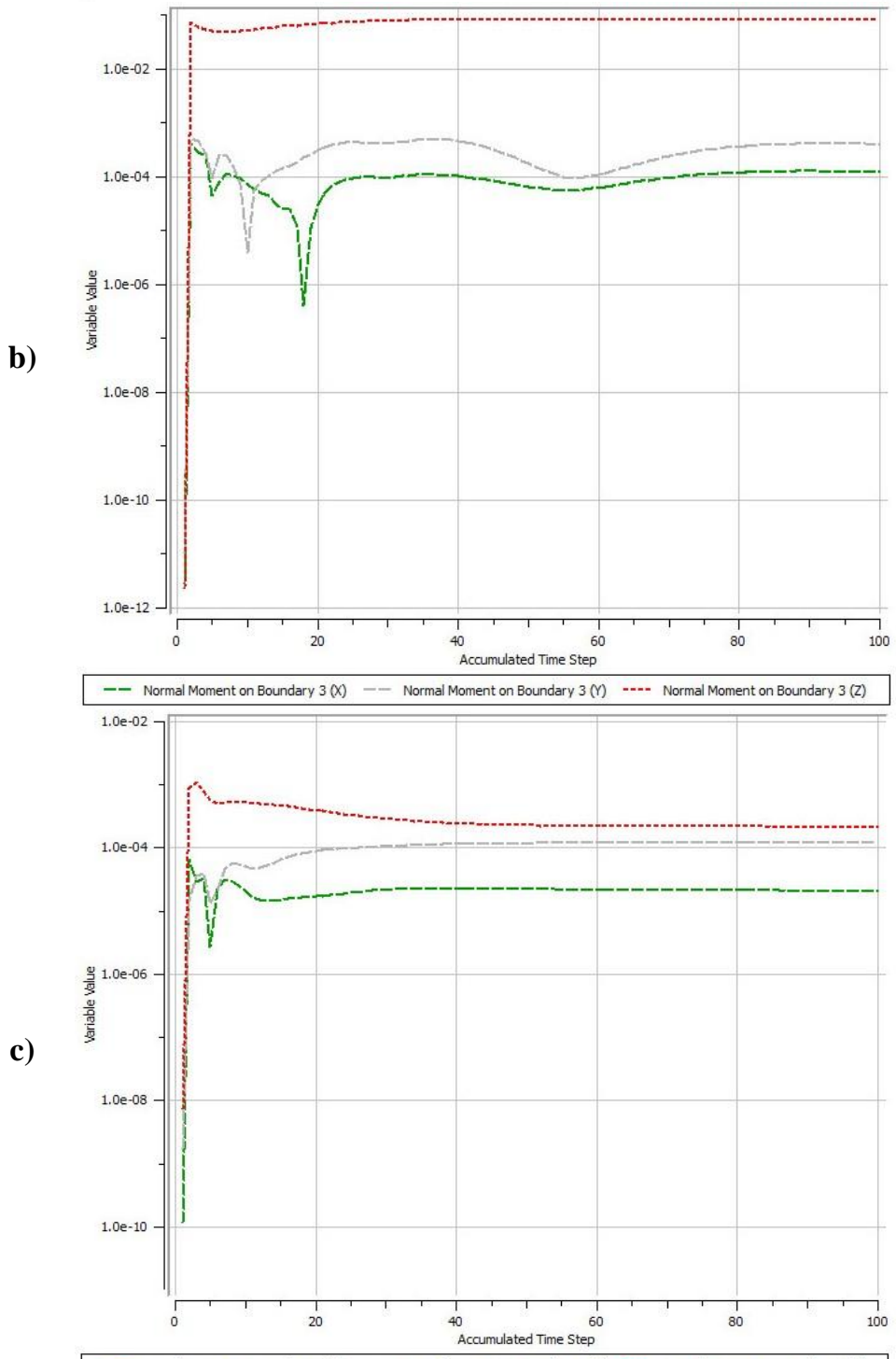

Figure 10 - The dependencies of the normal moment (on the three coordinate axes) during the fluid flow on the boundary 3 from time step of the solution: $a$ - the union cross; $b$ - the tee (model No. 1); $c$ - the tee (model No. 2).

ISPC Perspectives in science for 2017, 


\begin{tabular}{l|lrl|l|ll} 
& ISRA (India) & $=\mathbf{1 . 3 4 4}$ & SIS (USA) & $=\mathbf{0 . 9 1 2}$ & ICV (Poland) & $=\mathbf{6 . 6 3 0}$ \\
Impact Factor: & ISI (Dubai, UAE) $=\mathbf{0 . 8 2 9}$ & PUHL (Russia) $=\mathbf{0 . 2 3 4}$ & PIF (India) & $=\mathbf{1 . 9 4 0}$ \\
& GIF (Australia) & $\mathbf{0 . 5 6 4}$ & ESJI (KZ) & $=\mathbf{1 . 0 4 2}$ & IBI (India) & $=\mathbf{4 . 2 6 0}$ \\
& JIF & $\mathbf{1 . 5 0 0}$ & SJIF (Morocco) & $=\mathbf{2 . 0 3 1}$ & & \\
\hline
\end{tabular}

a)
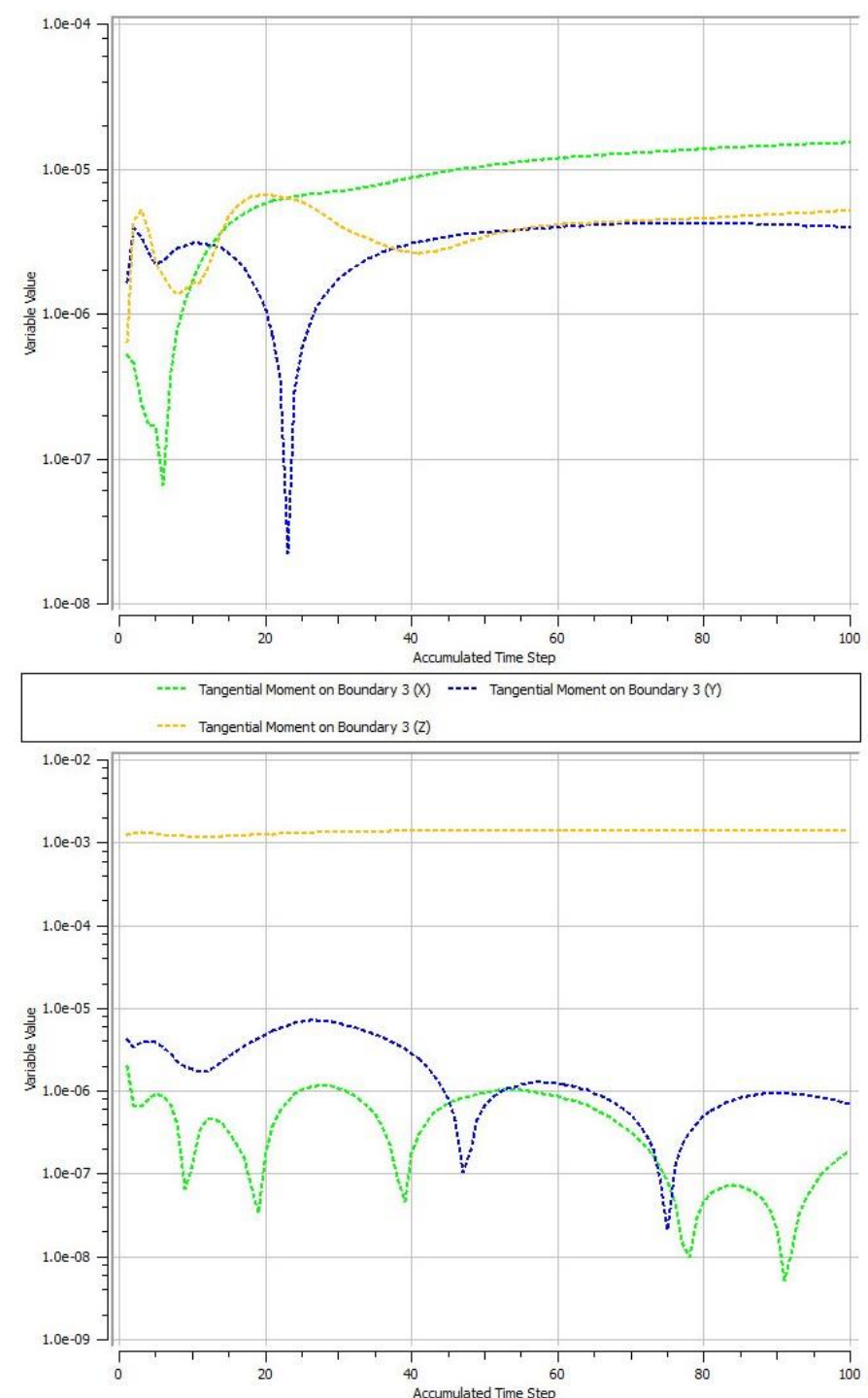

b)

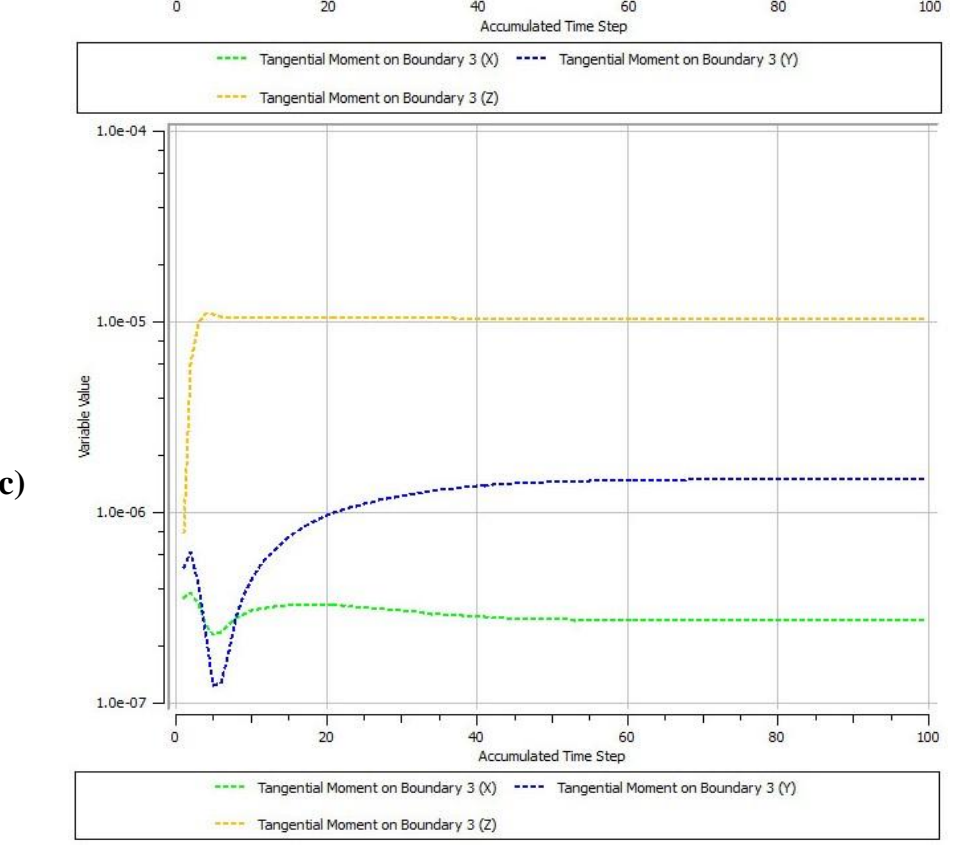

Figure 11 - The dependencies of the tangential moment (on the three coordinate axes) during the fluid flow on the boundary 3 from time step of the solution: $a$ - the union cross; $b$ - the tee (model No. 1); $c$ - the tee (model No. 2).

ISPC Perspectives in science for 2017, 


\begin{tabular}{l|lrl|l|ll} 
& ISRA (India) & $=\mathbf{1 . 3 4 4}$ & SIS (USA) & $=\mathbf{0 . 9 1 2}$ & ICV (Poland) & $=\mathbf{6 . 6 3 0}$ \\
Impact Factor: & ISI (Dubai, UAE) $=\mathbf{0 . 8 2 9}$ & PUHU (Russia) $=\mathbf{0 . 2 3 4}$ & PIF (India) & $=\mathbf{1 . 9 4 0}$ \\
& GIF (Australia) & $\mathbf{0 . 5 6 4}$ & ESJI (KZ) & $=\mathbf{1 . 0 4 2}$ & IBI (India) & $\mathbf{4 . 2 6 0}$
\end{tabular}

a)

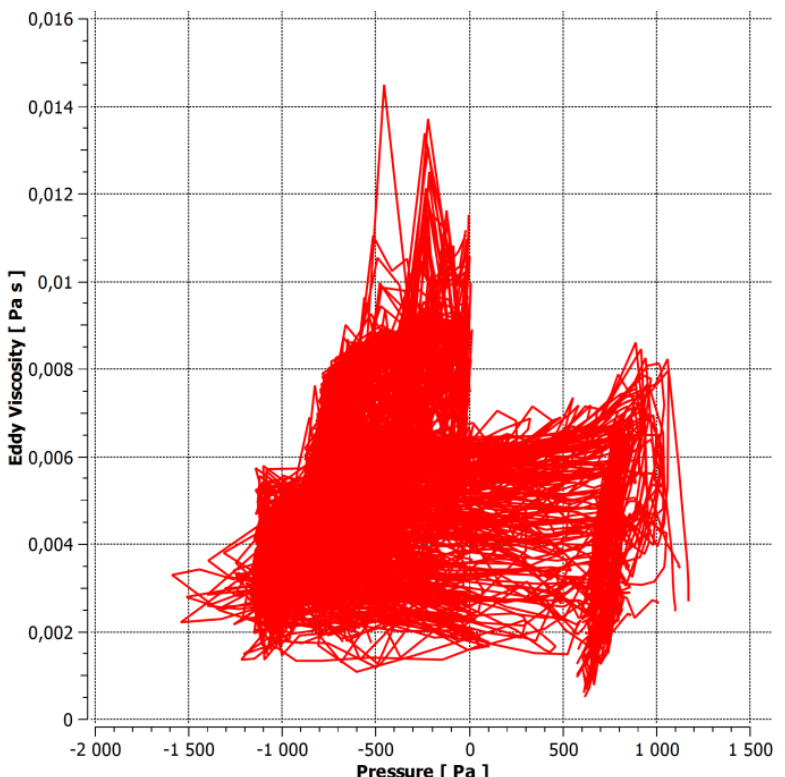

b)

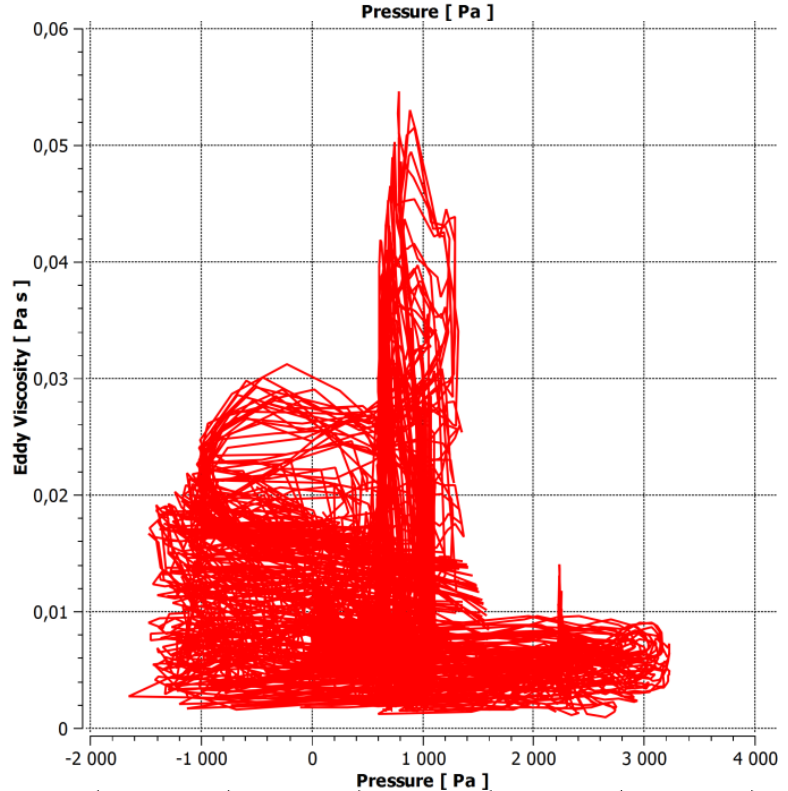

c)

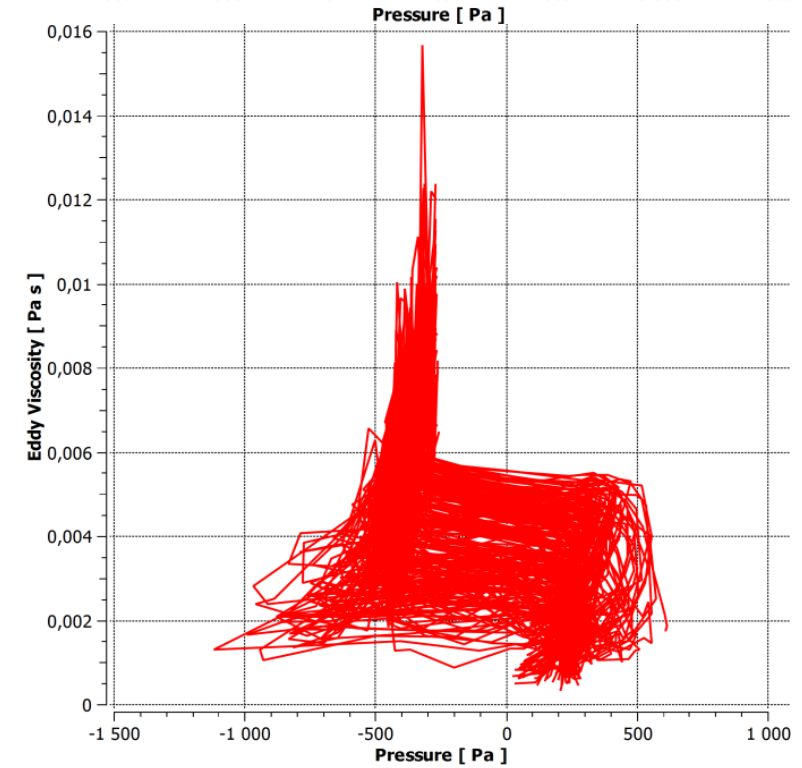

Figure 12 - The dependencies of the eddy viscosity from the fluid pressure: $a$ - the union cross; $b$ - the tee (model No. 1); $\mathrm{c}$ - the tee (model No. 2).

ISPC Perspectives in science for 2017, 


\begin{tabular}{l|lrl|l|ll} 
& ISRA (India) & $=\mathbf{1 . 3 4 4}$ & SIS (USA) & $=\mathbf{0 . 9 1 2}$ & ICV (Poland) & $=\mathbf{6 . 6 3 0}$ \\
Impact Factor: & ISI (Dubai, UAE) $=\mathbf{0 . 8 2 9}$ & PUHL (Russia) $=\mathbf{0 . 2 3 4}$ & PIF (India) & $=\mathbf{1 . 9 4 0}$ \\
& GIF (Australia) & $\mathbf{0 . 5 6 4}$ & ESJI (KZ) & $=\mathbf{1 . 0 4 2}$ & IBI (India) & $=\mathbf{4 . 2 6 0}$ \\
& JIF & $\mathbf{1 . 5 0 0}$ & SJIF (Morocco) & $=\mathbf{2 . 0 3 1}$ & & \\
\hline
\end{tabular}

a)

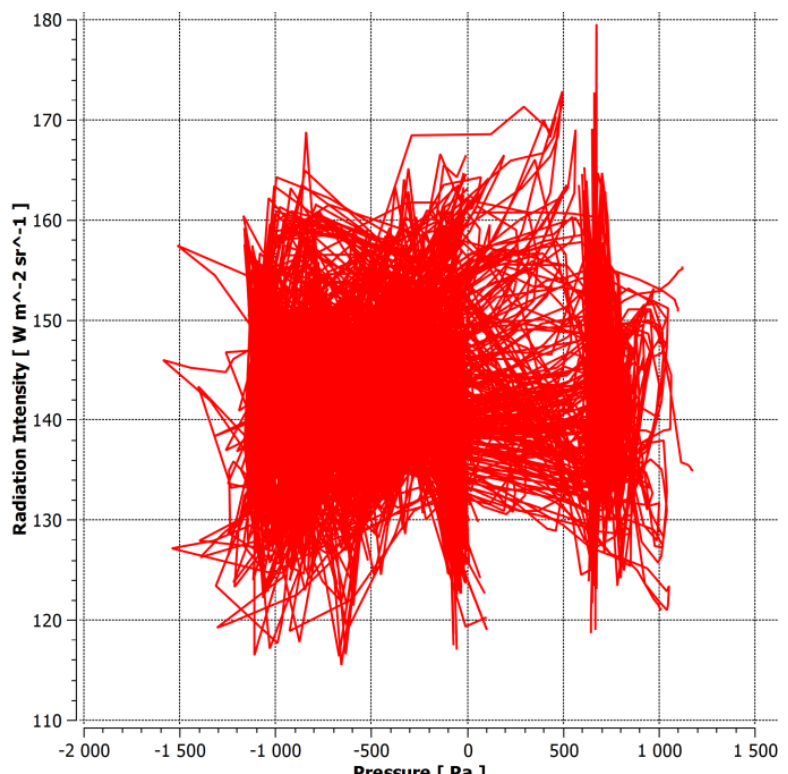

b)
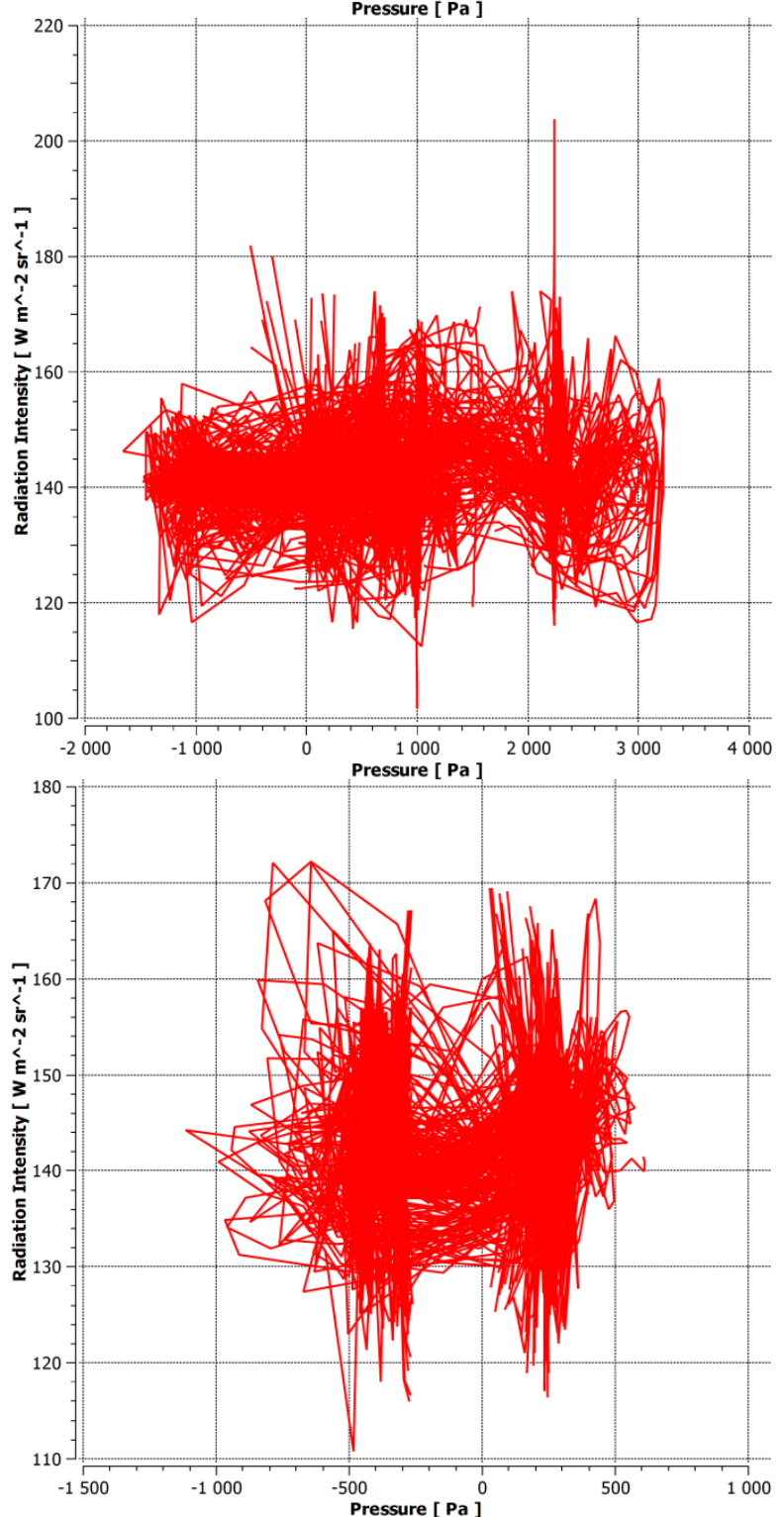

Figure 13 - The dependencies of the radiation intensity from the fluid pressure: $a$ - the union cross; $b$ - the tee (model No. 1); $\mathrm{c}$ - the tee (model No. 2).

ISPC Perspectives in science for 2017, 


\begin{tabular}{l|lrl|l|ll} 
& ISRA (India) & $=\mathbf{1 . 3 4 4}$ & SIS (USA) & $=\mathbf{0 . 9 1 2}$ & ICV (Poland) & $=\mathbf{6 . 6 3 0}$ \\
Impact Factor: & ISI (Dubai, UAE) $=\mathbf{0 . 8 2 9}$ & PUHU (Russia) $=\mathbf{0 . 2 3 4}$ & PIF (India) & $=\mathbf{1 . 9 4 0}$ \\
& GIF (Australia) & $\mathbf{0 . 5 6 4}$ & ESJI (KZ) & $=\mathbf{1 . 0 4 2}$ & IBI (India) & $\mathbf{4 . 2 6 0}$
\end{tabular}

a)

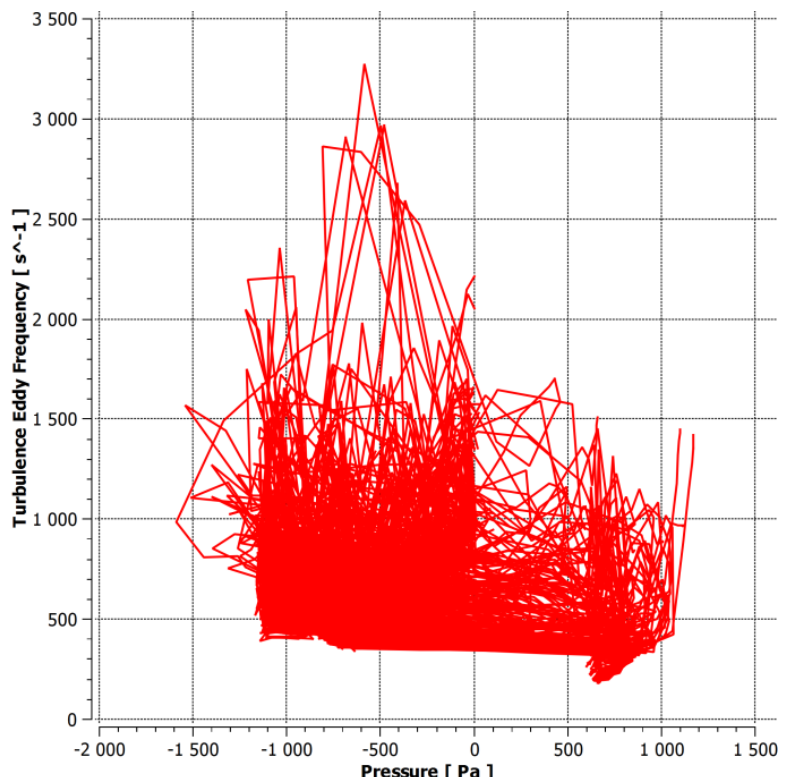

b)

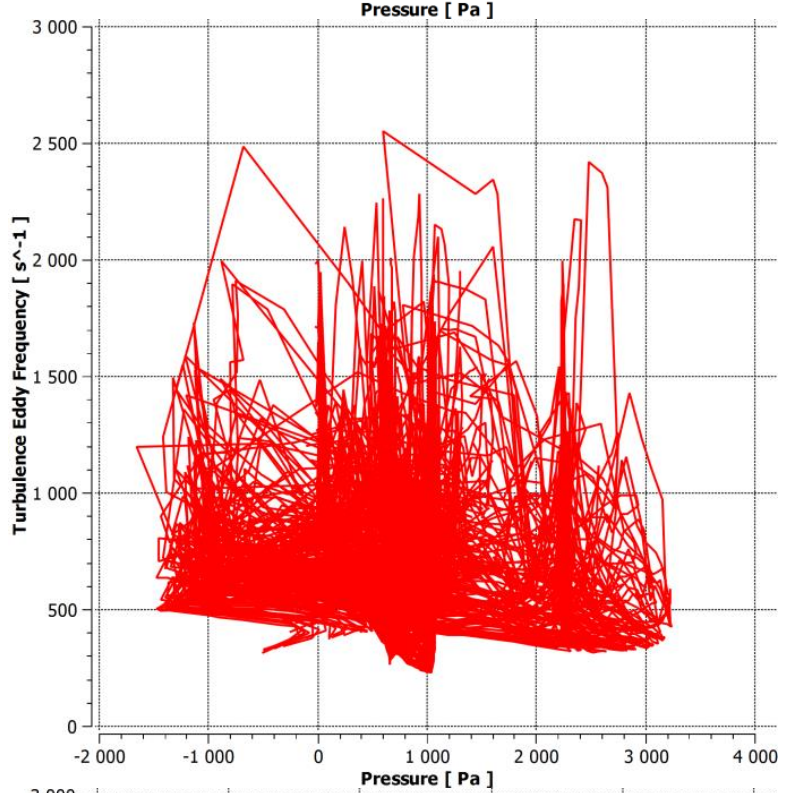

c)

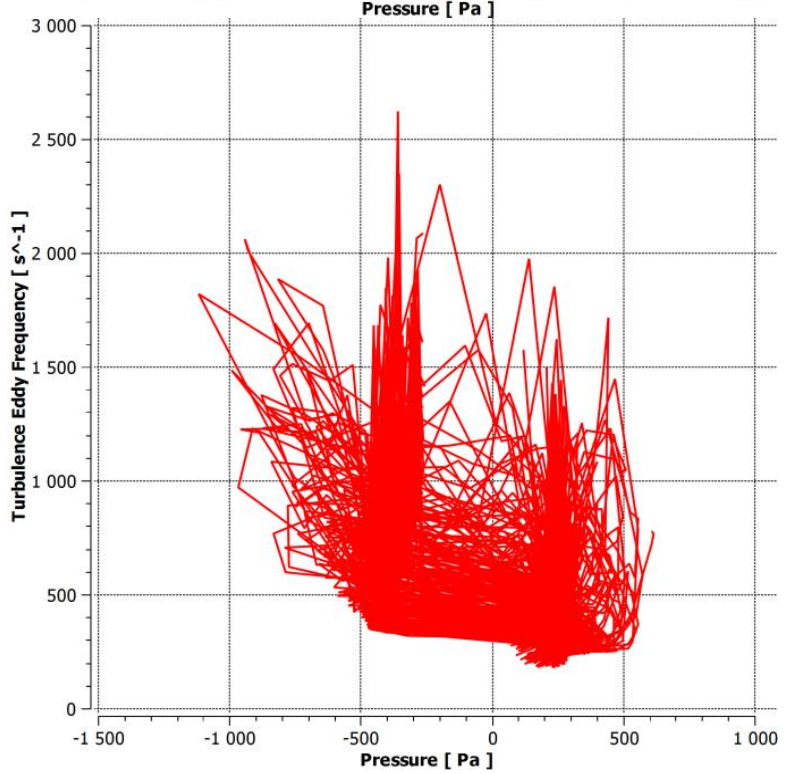

Figure 14 - The dependencies of the turbulence eddy frequency from the fluid pressure: a - the union cross; b - the tee (model No. 1); $\mathrm{c}$ - the tee (model No. 2 ).

ISPC Perspectives in science for 2017 , 


\begin{tabular}{l|lrl|l|ll} 
& ISRA (India) & $=\mathbf{1 . 3 4 4}$ & SIS (USA) & $=\mathbf{0 . 9 1 2}$ & ICV (Poland) & $=\mathbf{6 . 6 3 0}$ \\
Impact Factor: & ISI (Dubai, UAE) $=\mathbf{0 . 8 2 9}$ & PUHU (Russia) $=\mathbf{0 . 2 3 4}$ & PIF (India) & $=\mathbf{1 . 9 4 0}$ \\
& GIF (Australia) & $\mathbf{0 . 5 6 4}$ & ESJI (KZ) & $=\mathbf{1 . 0 4 2}$ & IBI (India) & $\mathbf{4 . 2 6 0}$
\end{tabular}

a)

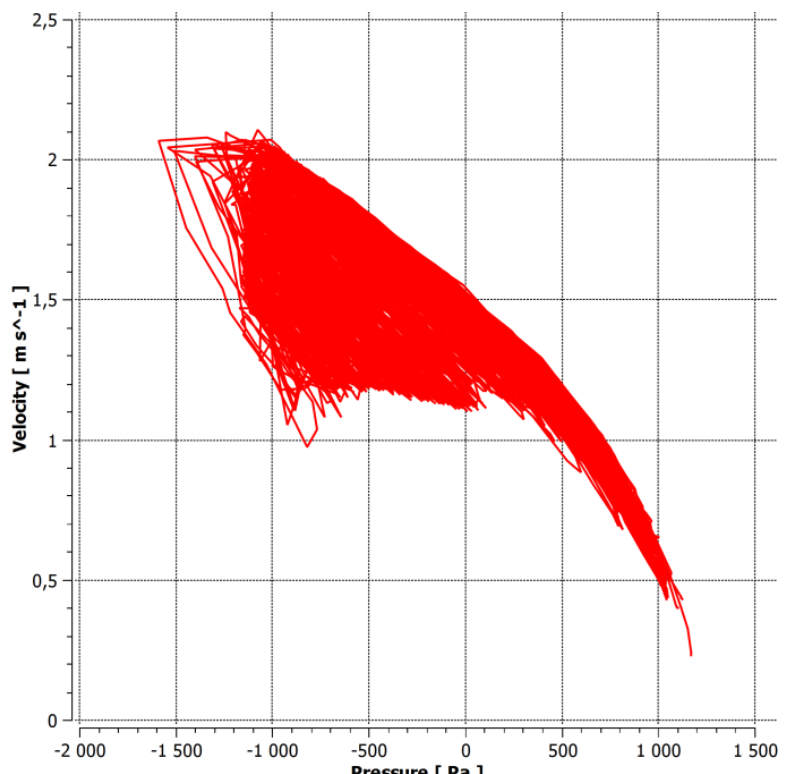

b)
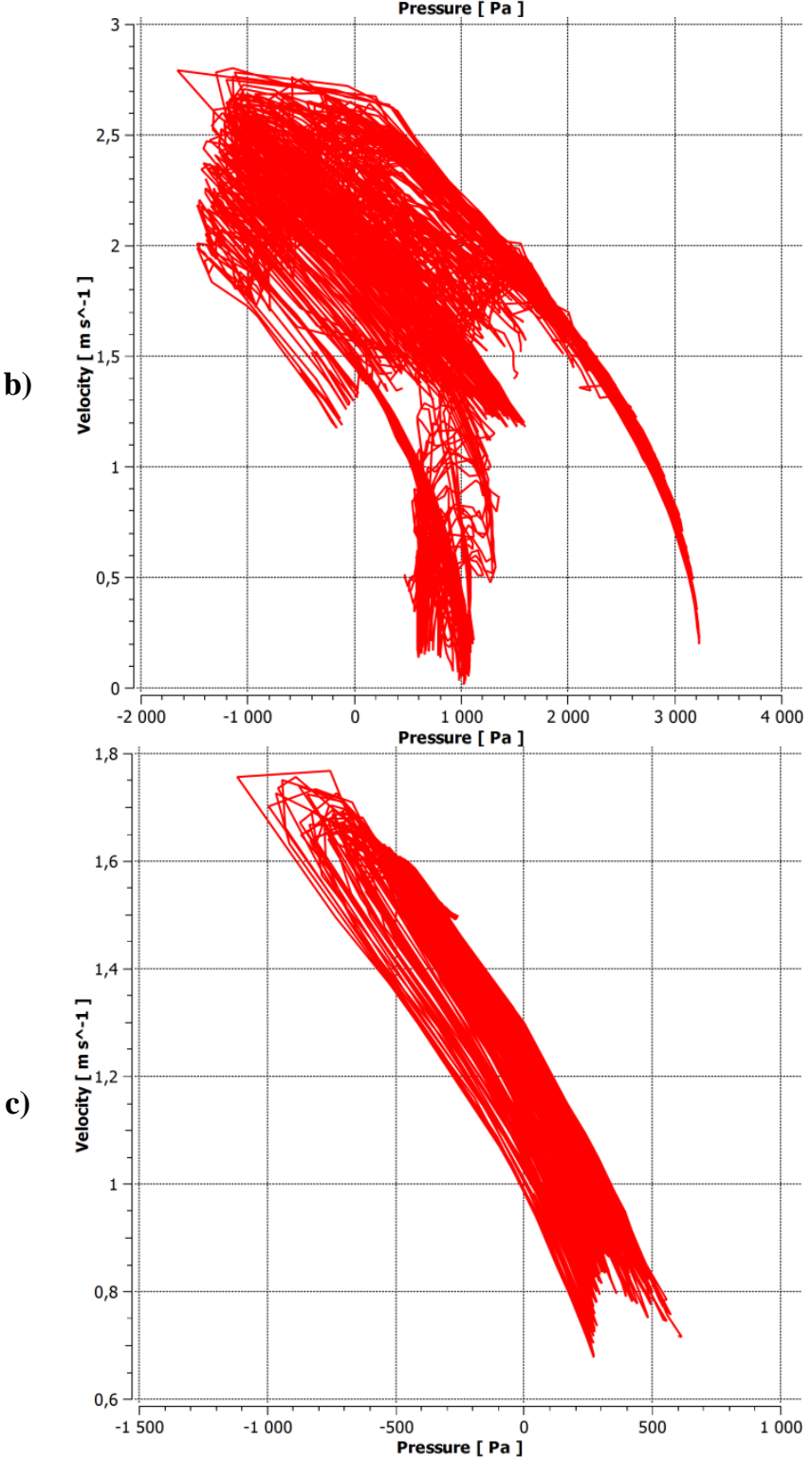

Figure 15 - The dependencies of the velocity of the fluid flow from the pressure: $a$ - the union cross; $b$ - the tee (model No. 1); $\mathrm{c}$ - the tee (model No. 2).

ISPC Perspectives in science for 2017, 


\begin{tabular}{l|lrl|l|ll} 
& ISRA (India) & $=\mathbf{1 . 3 4 4}$ & SIS (USA) & $=\mathbf{0 . 9 1 2}$ & ICV (Poland) & $=\mathbf{6 . 6 3 0}$ \\
Impact Factor: & ISI (Dubai, UAE) $=\mathbf{0 . 8 2 9}$ & PUHU (Russia) $=\mathbf{0 . 2 3 4}$ & PIF (India) & $=\mathbf{1 . 9 4 0}$ \\
& GIF (Australia) & $\mathbf{0 . 5 6 4}$ & ESJI (KZ) & $=\mathbf{1 . 0 4 2}$ & IBI (India) & $\mathbf{4 . 2 6 0}$
\end{tabular}

a)

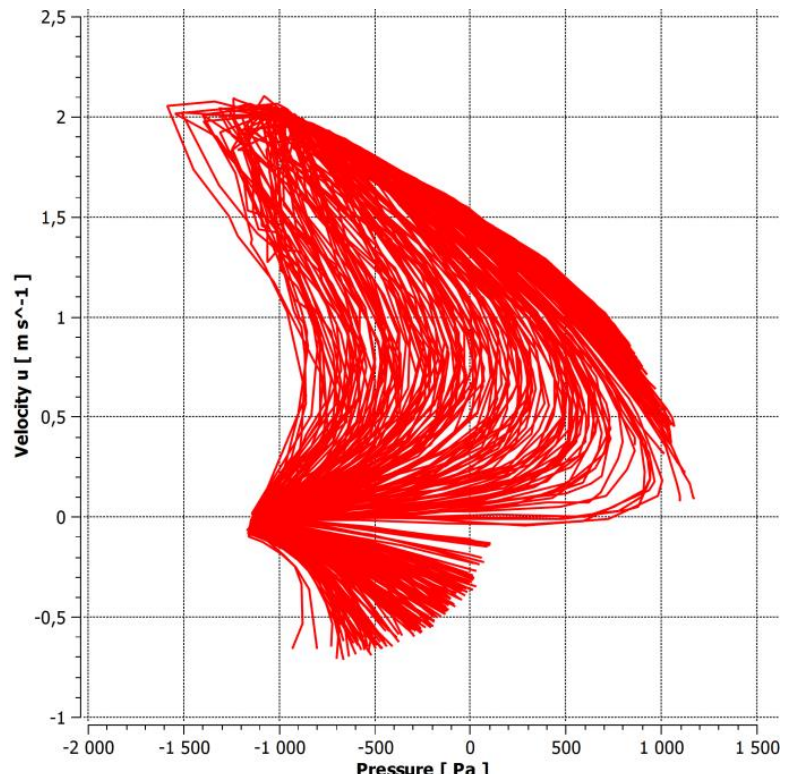

b)

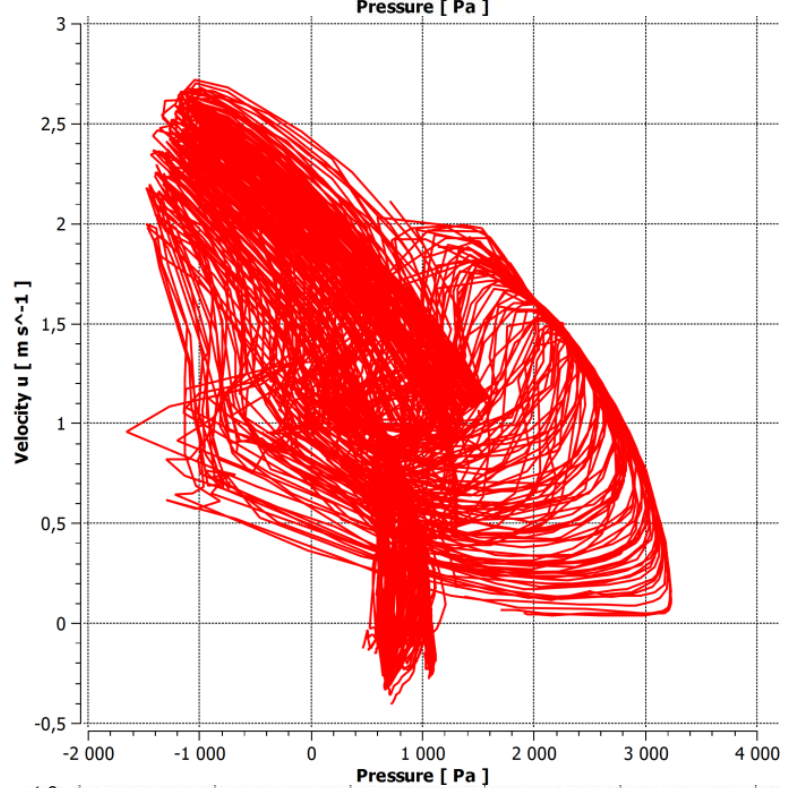

c)

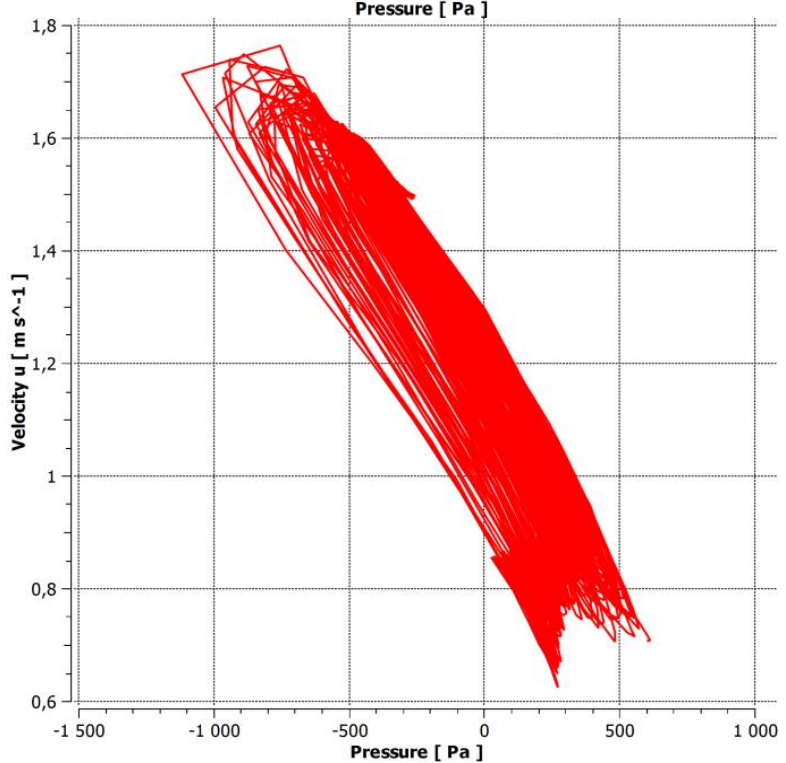

Figure 16 - The dependencies of the velocity $u$ of the fluid flow from the pressure: $a$ - the union cross; $b$ the tee (model No. 1); $\mathrm{c}$ - the tee (model No. 2). 


\begin{tabular}{l|lrl|l|ll} 
& ISRA (India) & $=\mathbf{1 . 3 4 4}$ & SIS (USA) & $=\mathbf{0 . 9 1 2}$ & ICV (Poland) & $=\mathbf{6 . 6 3 0}$ \\
Impact Factor: & ISI (Dubai, UAE) $=\mathbf{0 . 8 2 9}$ & PUHU (Russia) $=\mathbf{0 . 2 3 4}$ & PIF (India) & $=\mathbf{1 . 9 4 0}$ \\
& GIF (Australia) & $\mathbf{0 . 5 6 4}$ & ESJI (KZ) & $=\mathbf{1 . 0 4 2}$ & IBI (India) & $\mathbf{4 . 2 6 0}$
\end{tabular}

a)

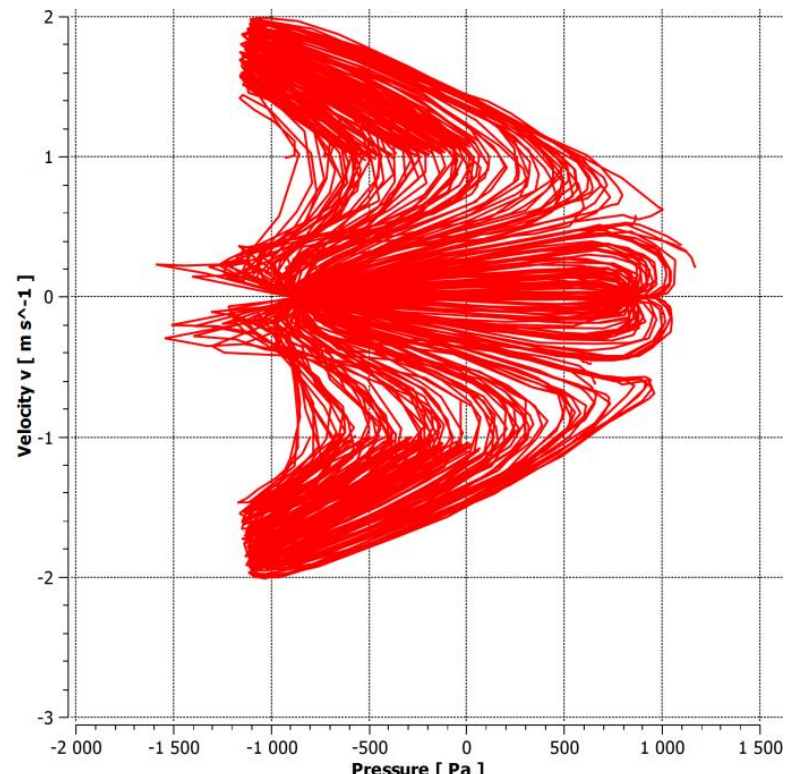

b)

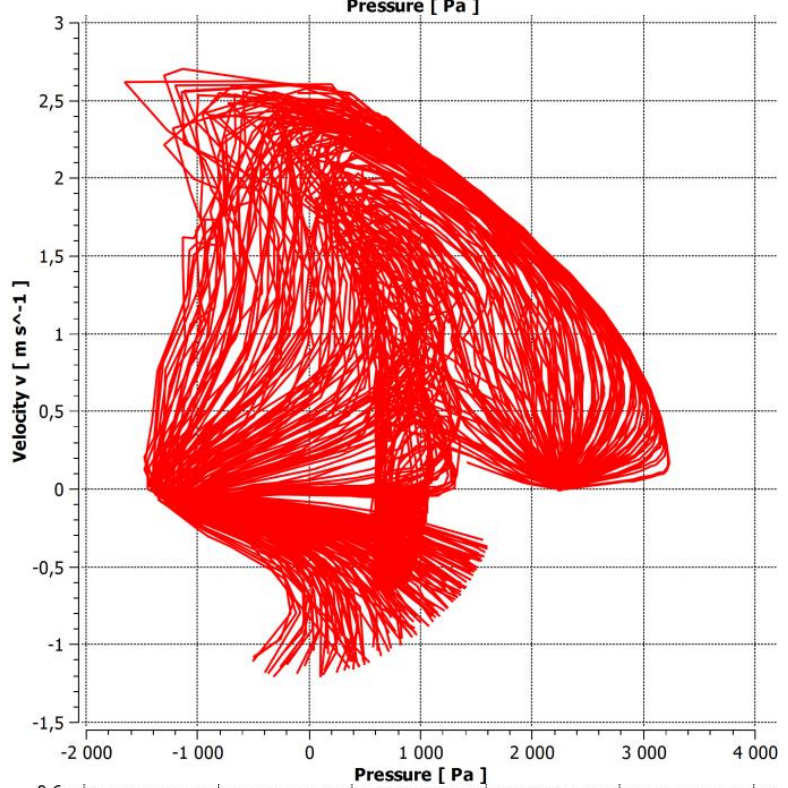

c)

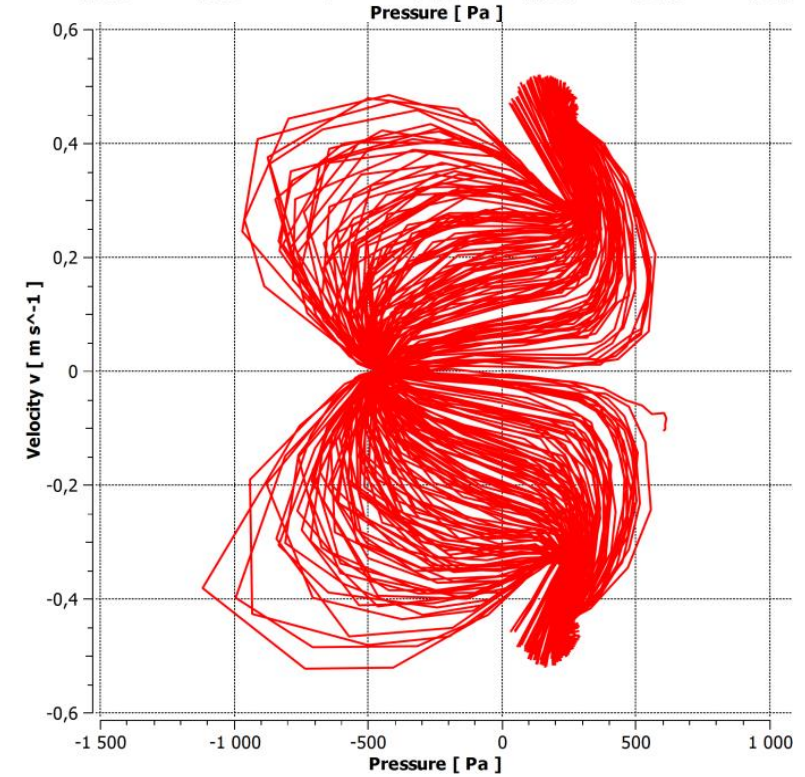

Figure 17 - The dependencies of the velocity $\mathrm{v}$ of the fluid flow from the pressure: $a$ - the union cross; $b$ - the tee (model No. 1); $\mathrm{c}$ - the tee (model No. 2). 


\begin{tabular}{l|lrl|l|ll} 
& ISRA (India) & $=\mathbf{1 . 3 4 4}$ & SIS (USA) & $=\mathbf{0 . 9 1 2}$ & ICV (Poland) & $=\mathbf{6 . 6 3 0}$ \\
Impact Factor: & ISI (Dubai, UAE) $=\mathbf{0 . 8 2 9}$ & PUHU (Russia) $=\mathbf{0 . 2 3 4}$ & PIF (India) & $=\mathbf{1 . 9 4 0}$ \\
& GIF (Australia) & $\mathbf{0 . 5 6 4}$ & ESJI (KZ) & $=\mathbf{1 . 0 4 2}$ & IBI (India) & $\mathbf{4 . 2 6 0}$
\end{tabular}

a)

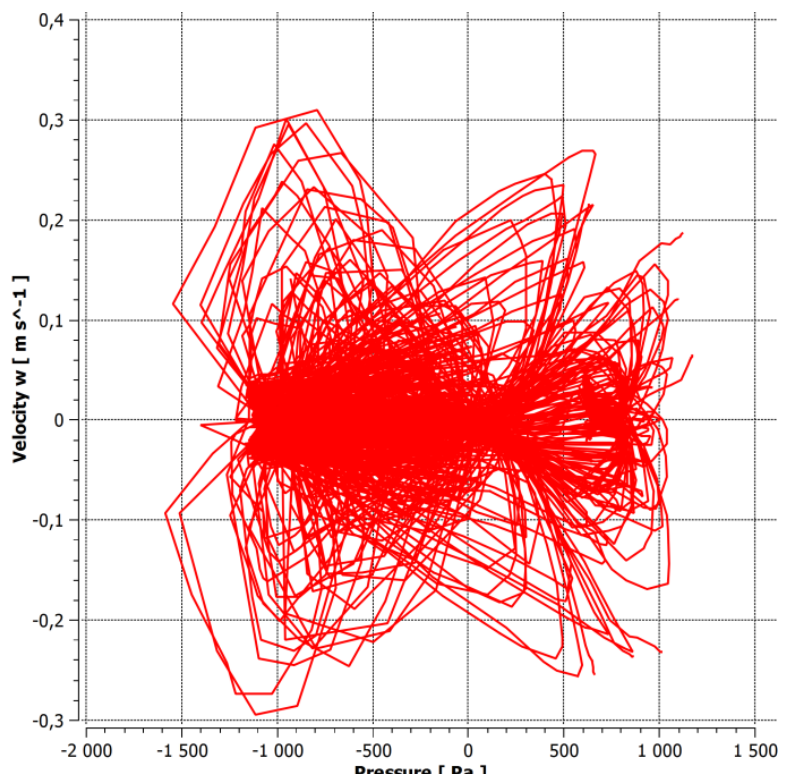

b)

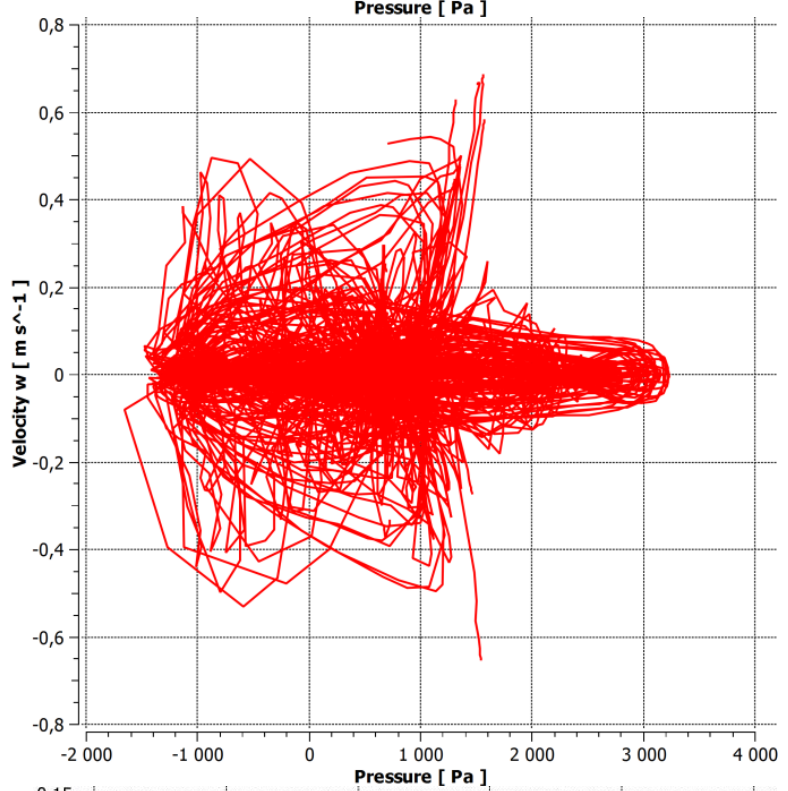

c)

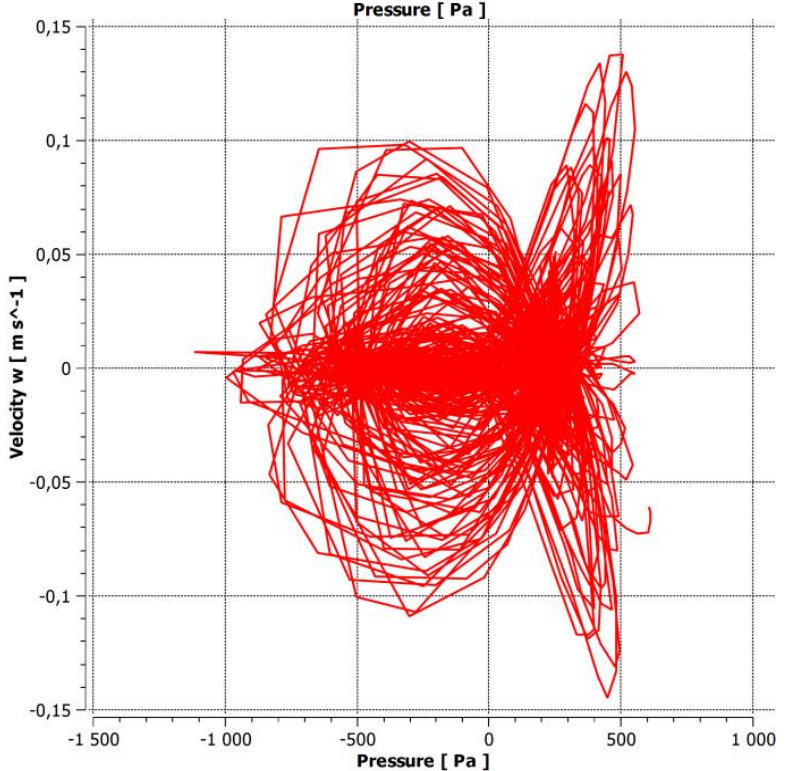

Figure 18 - The dependencies of the velocity $w$ of the fluid flow from the pressure: $a$ - the union cross; $b$ the tee (model No. 1); $\mathrm{c}$ - the tee (model No. 2).

ISPC Perspectives in science for 2017 , 


\begin{tabular}{l|lrl|l|ll} 
& ISRA (India) & $=\mathbf{1 . 3 4 4}$ & SIS (USA) & $=\mathbf{0 . 9 1 2}$ & ICV (Poland) & $=\mathbf{6 . 6 3 0}$ \\
Impact Factor: & ISI (Dubai, UAE) $=\mathbf{0 . 8 2 9}$ & PUHU (Russia) $=\mathbf{0 . 2 3 4}$ & PIF (India) & $=\mathbf{1 . 9 4 0}$ \\
& GIF (Australia) & $\mathbf{0 . 5 6 4}$ & ESJI (KZ) & $=\mathbf{1 . 0 4 2}$ & IBI (India) & $\mathbf{4 . 2 6 0}$
\end{tabular}

a)
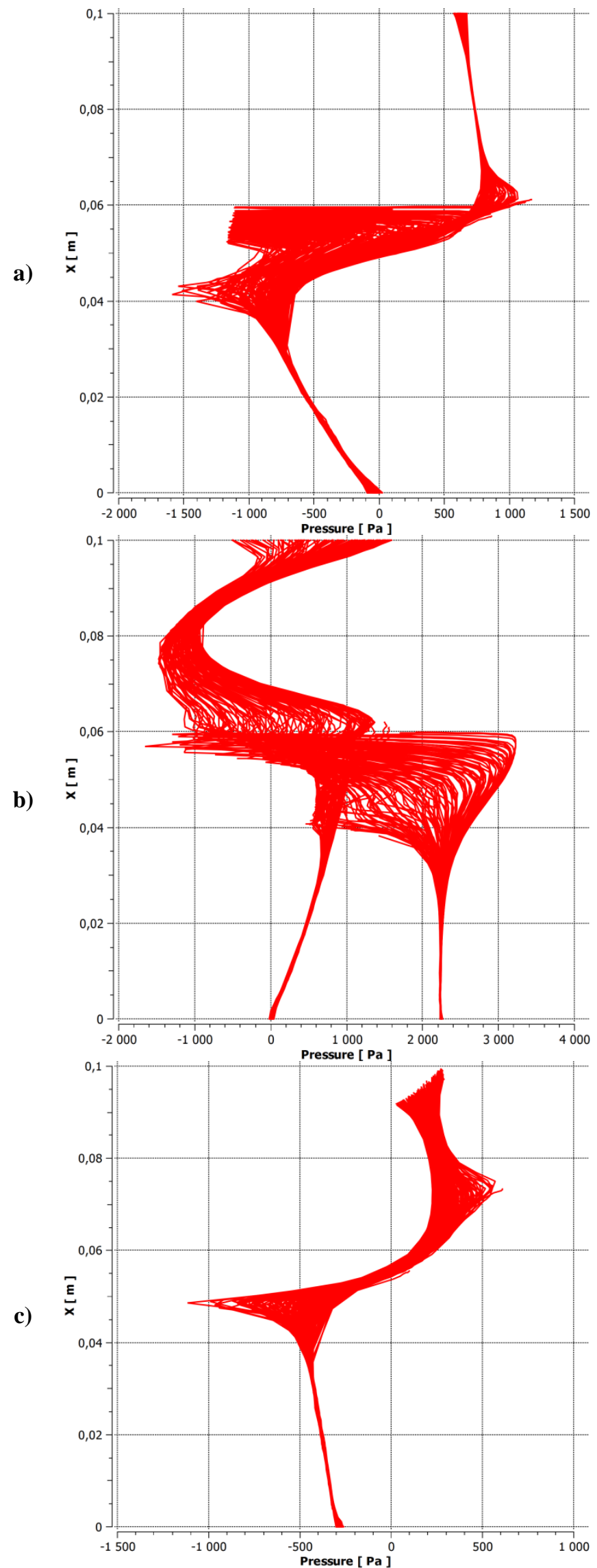

Figure 19 - The changes of the fluid pressure in the channels of the pipeline (along the coordinate axis $\mathrm{X}$ ): a - the union cross; $b$ - the tee (model No. 1); $c$ - the tee (model No. 2). 


\begin{tabular}{l|lrl|l|ll} 
& ISRA (India) & $=\mathbf{1 . 3 4 4}$ & SIS (USA) & $=\mathbf{0 . 9 1 2}$ & ICV (Poland) & $=\mathbf{6 . 6 3 0}$ \\
Impact Factor: & ISI (Dubai, UAE) $=\mathbf{0 . 8 2 9}$ & PUHU (Russia) $=\mathbf{0 . 2 3 4}$ & PIF (India) & $=\mathbf{1 . 9 4 0}$ \\
& GIF (Australia) & $\mathbf{0 . 5 6 4}$ & ESJI (KZ) & $=\mathbf{1 . 0 4 2}$ & IBI (India) & $\mathbf{4 . 2 6 0}$
\end{tabular}

a)

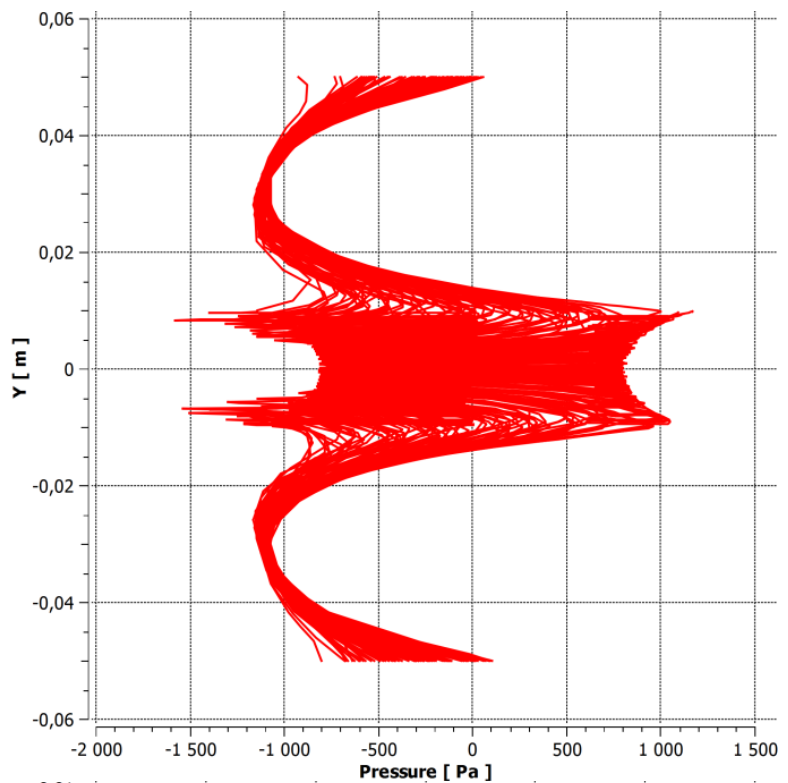

b)

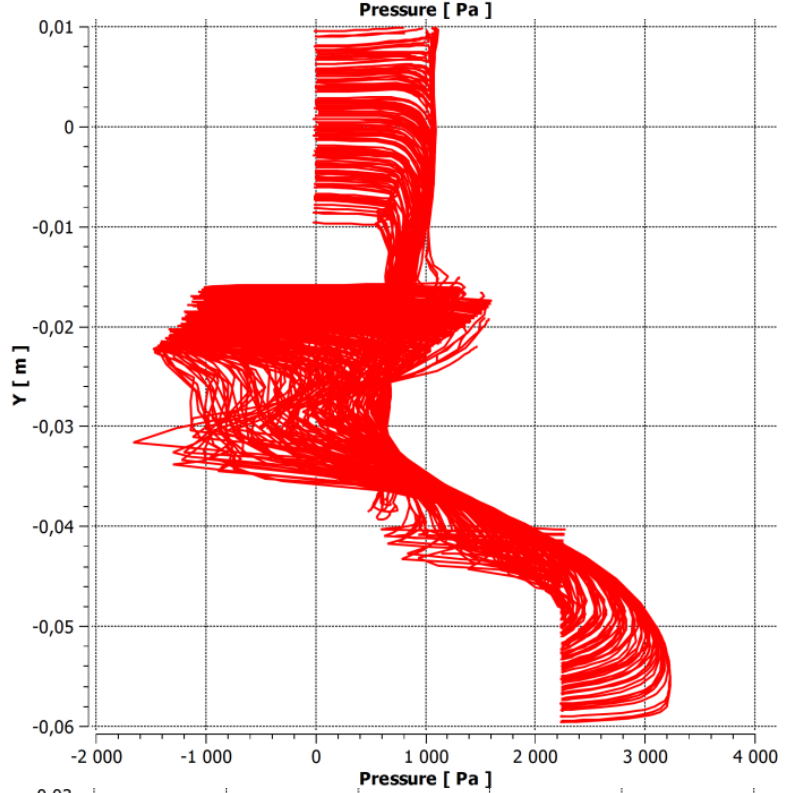

c)

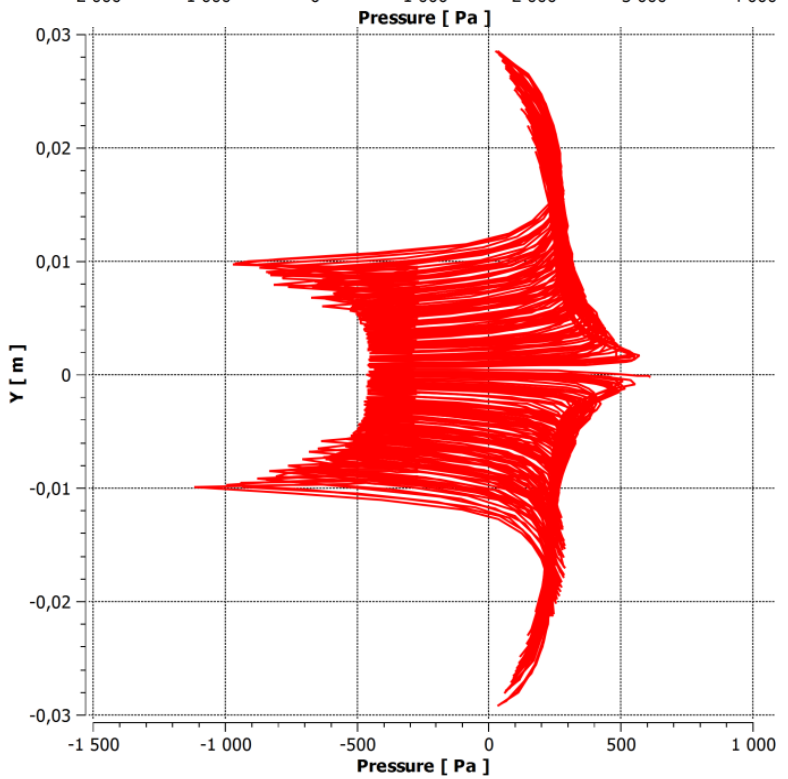

Figure 20 - The changes of the fluid pressure in the channels of the pipeline (along the coordinate axis Y): a - the union cross; $b$ - the tee (model No. 1); $c$ - the tee (model No. 2 ).

ISPC Perspectives in science for 2017, 


\begin{tabular}{l|lrl|l|ll} 
& ISRA (India) & $=\mathbf{1 . 3 4 4}$ & SIS (USA) & $=\mathbf{0 . 9 1 2}$ & ICV (Poland) & $=\mathbf{6 . 6 3 0}$ \\
Impact Factor: & ISI (Dubai, UAE) $=\mathbf{0 . 8 2 9}$ & PUHU (Russia) $=\mathbf{0 . 2 3 4}$ & PIF (India) & $=\mathbf{1 . 9 4 0}$ \\
& GIF (Australia) & $\mathbf{0 . 5 6 4}$ & ESJI (KZ) & $=\mathbf{1 . 0 4 2}$ & IBI (India) & $\mathbf{4 . 2 6 0}$
\end{tabular}

a)
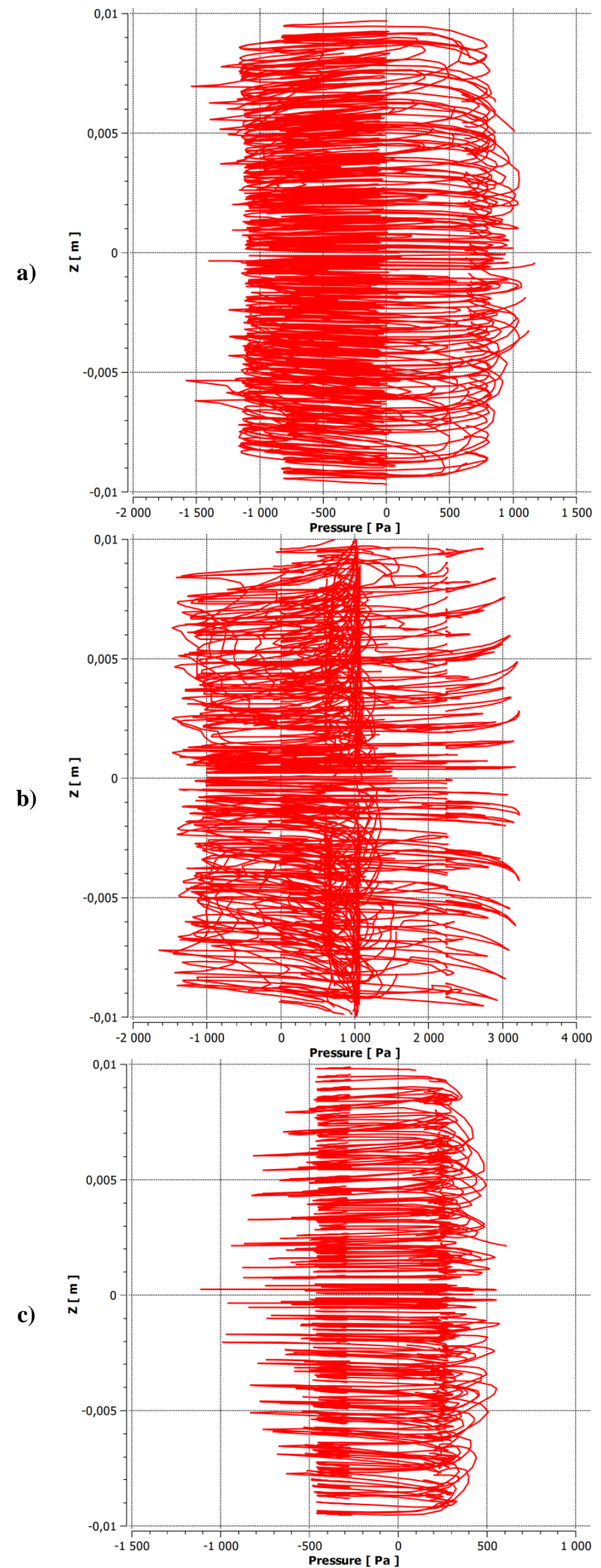

Figure 21 - The changes of the fluid pressure in the channels of the pipeline (along the coordinate axis Z): a the union cross; $b$ - the tee (model No. 1$) ; \mathrm{c}$ - the tee (model No. 2$)$.

ISPC Perspectives in science for 2017, 
The thermal radiation reaches a maximum in the turbulent flow with the positive fluid pressure (the union cross and the tee with two outlets). In the tee with one outlet are observed the same changes of the thermal radiation when the acting positive and negative pressures.

The greatest turbulence eddy frequency was defined at the negative fluid pressure in the union cross.

With the increase of the positive pressure, the flow velocity is decreased in the all pipelines with the local hydraulic resistances. With the increase of the negative pressure, the flow velocity is increased.

On the length of the longitudinal channel of the union cross, before the branching, the negative fluid pressure acts. The pressure on this section is increased. In the longitudinal channel, after the branching, the positive fluid pressure acts. Simultaneously the negative and positive fluid pressures in the moment of the flow dividing act in the transverse channel of the union cross. Similarly, the change in the fluid pressure (pressure drop less in 1.7 times) in the tee with two outlets is occurred. In the two input channels of the tee positive pressure in the transition flow is replaced by negative in the turbulent flow in the transverse and outlet channels. In the cross section (Z-axis) of the all channels of the pipelines from the centerline to the surface of the inner wall there are similar jumps of the positive and negative values of the fluid pressure.

The compares of the calculated values of the parameters of the fluid flow in the pipelines with the local hydraulic resistances is presented in the summary table 1 .

The comparison of the calculated parameter values.

Table 1

\begin{tabular}{|c|c|c|c|}
\hline \multirow{2}{*}{ Parameter name } & \multicolumn{3}{|c|}{ Parameter value } \\
\hline & Union cross & Tee (model No. 1) & Tee (model No. 2) \\
\hline Global length & 0.038539 & 0.039122 & 0.035161 \\
\hline Minimum extent & \multicolumn{3}{|c|}{0.02} \\
\hline Maximum extent & \multicolumn{2}{|c|}{0.1} & 0.099542 \\
\hline Density & \multicolumn{3}{|c|}{997} \\
\hline Dynamic viscosity & \multicolumn{3}{|c|}{0.0008899} \\
\hline Velocity & 1.3169 & 1.3303 & 1.1877 \\
\hline Velocity u & $-0.764 / 2.15$ & $-1.50 / 2.75$ & $0.493 / 1.81$ \\
\hline Velocity v & $-2.02 / 2.01$ & $-1.24 / 2.81$ & $-0.585 / 0.56$ \\
\hline Velocity w & $-0.431 / 0.464$ & $-0.784 / 0.807$ & $-0.175 / 0.183$ \\
\hline Advection time & 0.029266 & 0.029408 & 0.029604 \\
\hline Reynolds number & 56859 & 58308 & 46788 \\
\hline Total extinction coefficient [13] & \multicolumn{3}{|c|}{ 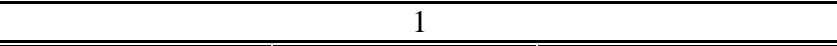 } \\
\hline Optical thickness & 0.038539 & 0.039122 & 0.035161 \\
\hline Specific heat capacity at constant pressure & \multicolumn{3}{|c|}{4180} \\
\hline Thermal conductivity & \multicolumn{3}{|c|}{0.607} \\
\hline Static entropy & \multicolumn{3}{|c|}{0} \\
\hline Total absorption coefficient [14] & \multicolumn{3}{|c|}{ 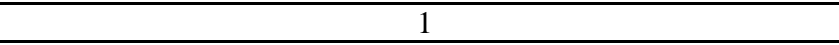 } \\
\hline Total scattering coefficient & \multicolumn{3}{|c|}{0} \\
\hline Radiation intensity & $90.1 / 202$ & $61.7 / 234$ & $99.7 / 181$ \\
\hline Pressure & -1730/1170 & $-2570 / 3250$ & $-1340 / 666$ \\
\hline Eddy viscosity & $0.000229 / 0.0192$ & $0.000711 / 0.0557$ & $0.000181 / 0.0184$ \\
\hline Turbulence eddy frequency & $182 / 4000$ & $155 / 4070$ & $182 / 3530$ \\
\hline Reynolds stress uu & $0.000111 / 0.00562$ & 0.000472/0.0233 & $0.000195 / 0.00562$ \\
\hline Reynolds stress vv & $0.000214 / 0.00562$ & $0.000754 / 0.0328$ & $0.000239 / 0.00562$ \\
\hline Reynolds stress ww & $0.000254 / 0.00562$ & $0.000829 / 0.0363$ & $0.000238 / 0.00562$ \\
\hline Reynolds stress uv & $-0.00122 / 0.00143$ & $-0.00593 / 0.0135$ & $-0.000132 / 0.000182$ \\
\hline Reynolds stress uw & $-0.000477 / 0.000424$ & $-0.00167 / 0.00199$ & $-0.000125 / 0.000134$ \\
\hline Reynolds stress vw & $-0.000374 / 0.000486$ & $-0.00379 / 0.0046$ & $\begin{array}{l}-0.0000805 / 0.0000782 \\
\end{array}$ \\
\hline Temperature & \multicolumn{3}{|c|}{298} \\
\hline Wall distance & 0.000107/0.0081 & $0.000113 / 0.00737$ & 0.0000814/0.00769 \\
\hline
\end{tabular}




\begin{tabular}{|c|c|c|c|c|c|c|}
\hline Impact Factor: & $\begin{array}{l}\text { ISRA (India) } \\
\text { ISI (Dubai, UAB } \\
\text { GIF (Australia) } \\
\text { JIF }\end{array}$ & $\begin{array}{r}=1.344 \\
=0.829 \\
=0.564 \\
=1.500\end{array}$ & $\begin{array}{l}\text { SIS (USA) } \\
\text { PИHЦ (Russia) } \\
\text { ESJI (KZ) } \\
\text { SJIF (Morocco) }\end{array}$ & $\begin{array}{l}=0.912 \\
=0.234 \\
=1.042 \\
=2.031\end{array}$ & $\begin{array}{l}\text { ICV (Poland) } \\
\text { PIF (India) } \\
\text { IBI (India) }\end{array}$ & $\begin{array}{l}=6.630 \\
=1.940 \\
=4.260\end{array}$ \\
\hline
\end{tabular}

In the table the numerator is the minimum value of the parameter, the denominator is the maximum value of the parameter.

\section{Conclusion}

1. The calculated values of average, minimum and maximum velocities and three-dimensional visual representation of the character of the fluid flow in the channels of the union cross and the tees with one and two outlets are received. Developed turbulent flow was defined at the confluence of the fluid flows. When dividing of the flow a laminar regime of the fluid flow is not saved (transient mode).

2. The greatest pressure drop is occurred in the tee with two inlets and one outlet channels. Minimum hydraulic pressure acted in the tee with one outlet channel.

3. Laminar flow regime is characterized action by the negative fluid pressure in the channels of the pipeline, the turbulent regime - the action of the positive fluid pressure.

\section{References:}

1. Chemezov D, Palev N (2016) Analytical models of the turbulent fluid flow in a circular pipe. ISJ Theoretical \& Applied Science, 09 (41): 77-84. Soi: http://s-o-i.org/1.1/TAS-0941-12 Doi: http://dx.doi.org/10.15863/TAS.2016.09.41.12

2. Syanov SL (2013) Numerical and experimental research the pressure drop in a pipe of variable cross section. PNRPU Mechanics Bulletin, №2. - pp. $176-185$.

3. Chemezov DA, Bayakina AV (2014) Simulation modeling of water flow in the Venturi nozzle. ISJ Theoretical \& Applied Science 07 (15): 25-29. Doi: http://dx.doi.org/10.15863/TAS.2014.07.15.4

4. Chemezov D (2016) The character of the fluid flow in the pipelines with the local hydraulic resistances. ISJ Theoretical \& Applied Science, 12 (44): 62-68. Soi: http://s-o-i.org/1.1/TAS-1244-13

Doi: http://dx.doi.org/10.15863/TAS.2016.12.44.13

5. Chemezov DA, Tyurina SI, Bayakina AV, Goremykin VV (2014) Fluid transients flow in piping elbow. ISJ Theoretical \& Applied Science $12 \quad$ (20): 4-8. Doi: http://dx.doi.org/10.15863/TAS.2014.12.20.2

6. Chemezov DA (2016) Mathematical modeling of change the properties of water at heating in the COMSOL MULTIPHYSICS software package. Materials XV of the International scientific and practical conference «Fundamental and applied researches in the modern world», 4 October, Vol. 1, St. Petersburg. - pp. $50-54$.
7. Chemezov D, Bayakina A (2016) The simulation of the fluid flow on the inner wall of the circular pipe. ISJ Theoretical \& Applied Science, 10 (42): 1-3. Soi: http://s-oi.org/1.1/TAS-10-42-1 Doi: http://dx.doi.org/10.15863/TAS.2016.10.42.1

8. Baykov VN, Volynov MA (2013) Mutual consistency of regularities demonstrated by the flow and hydraulic resistance. Vestnik MGSU, №5. - pp. 133 - 140 .

9. Rubinstein RY, Kroese DP (2017) Simulation and the Monte Carlo Method (second edition). New York: John Wiley \& Sons.

10. Kozelkov AS, Kurulin VV, Puchkova OL, Lashkin SV (2014) Simulation of turbulent flows using an algebraic Reynolds stress model with universal wall functions. COMPUTATIONAL CONTINUUM MECHANICS, №1 (7). - pp. 40 - 51.

11. (2017) Advection. Available: https://en.wikipedia.org/wiki/Advection (Accessed: 16.01.2017).

12. (2017) Rhie-Chow interpolation. Available: https://www.cfd-online.com/Wiki/RhieChow interpolation (Accessed: 16.01.2017).

13. (2017) Complex refractive index. Available: https://en.wikipedia.org/wiki/Refractive index\# Complex_refractive_index

(Accessed: 16.01.2017).

14. (2017) Absorption coefficient. Available: http://www.chemeurope.com/en/encyclopedia/ Absorption_coefficient.html 16.01.2017). 